\title{
Glycosides for Peripheral Neuropathic Pain: A Potential Medicinal Components
}

\author{
Miao-Miao Tian ${ }^{1,+}{ }^{+}$, Yu-Xiang Li ${ }^{2,+}$, Shan Liu ${ }^{1,+}{ }^{,}$, Chun-Hao Zhu ${ }^{1}$, Xiao-Bing Lan ${ }^{1}$, Juan Du ${ }^{1}$, Lin Ma ${ }^{1}$, \\ Jia-Mei Yang ${ }^{1}$, Ping Zheng ${ }^{1, *}$, Jian-Qiang Yu ${ }^{1,3, *}$ and Ning Liu ${ }^{1,3, *}$
}

check for updates

Citation: Tian, M.-M.; Li, Y.-X.; Liu, S.; Zhu, C.-H.; Lan, X.-B.; Du, J.; Ma, L.; Yang, J.-M.; Zheng, P.; Yu, J.-Q.; et al. Glycosides for Peripheral Neuropathic Pain: A Potential Medicinal Components. Molecules 2022, 27, 255. https://doi.org/ $10.3390 /$ molecules 27010255 Academic Editor: William A. Denny

Received: 30 October 2021

Accepted: 24 December 2021

Published: 31 December 2021

Publisher's Note: MDPI stays neutral with regard to jurisdictional claims in published maps and institutional affiliations.

Copyright: (C) 2021 by the authors. Licensee MDPI, Basel, Switzerland. This article is an open access article distributed under the terms and conditions of the Creative Commons Attribution (CC BY) license (https:// creativecommons.org/licenses/by/ $4.0 /)$.
1 Department of Pharmacology, School of Pharmacy, Ningxia Medical University, 1160 Shengli Street, Yinchuan 750004, China; t_tmiaomiao@163.com (M.-M.T.); daliushanzi12@163.com (S.L.); zchdegree@163.com (C.-H.Z.); lanxbing@163.com (X.-B.L.); dujuand@163.com (J.D.); malinzill@sina.com (L.M.); m15809581390@163.com (J.-M.Y.)

2 College of Nursing, Ningxia Medical University, 1160 Shengli Street, Yinchuan 750004, China; li_yuxiang@163.com

3 Ningxia Special Traditional Medicine Modern Engineering Research Center and Collaborative Innovation Center, Ningxia Medical University, 1160 Shengli Street, Yinchuan 750004, China

* Correspondence: zhengping2004@126.com (P.Z.); YujqLab@163.com (J.-Q.Y.); liuningkimi@163.com (N.L.)

+ These authors contributed equally to this work.

\begin{abstract}
Neuropathic pain is a refractory disease that occurs across the world and pharmacotherapy has limited efficacy and/or safety. This disease imposes a significant burden on both the somatic and mental health of patients; indeed, some patients have referred to neuropathic pain as being 'worse than death'. The pharmacological agents that are used to treat neuropathic pain at present can produce mild effects in certain patients, and induce many adverse reactions, such as sedation, dizziness, vomiting, and peripheral oedema. Therefore, there is an urgent need to discover novel drugs that are safer and more effective. Natural compounds from medical plants have become potential sources of analgesics, and evidence has shown that glycosides alleviated neuropathic pain via regulating oxidative stress, transcriptional regulation, ion channels, membrane receptors and so on. In this review, we summarize the epidemiology of neuropathic pain and the existing therapeutic drugs used for disease prevention and treatment. We also demonstrate how glycosides exhibit an antinociceptive effect on neuropathic pain in laboratory research and describe the antinociceptive mechanisms involved to facilitate the discovery of new drugs to improve the quality of life of patients experiencing neuropathic pain.
\end{abstract}

Keywords: neuropathic pain; epidemiology; glycosides; oxidative stress; transcriptional regulation; ion channels; membrane receptors

\section{Introduction}

Neuropathic pain is defined by the International Association for the Study of Pain (IASP) as pain arising as a direct consequence of a lesion or disease affecting the somatosensory system [1]. Following injury, the structure and function of the somatosensory nervous system undergoes a variety of chronic and pathological changes that will eventually lead to the pathological amplification of nociceptive and non-noxious stimulus signals. Collectively, these events lead to neuropathic pain, and this is usually accompanied by anatomical and physiological changes in the central nervous system (CNS) or peripheral nervous system (PNS) [2]. Gene mutations in the PNS may give rise to the alteration of receptors and ion channels that underlie certain rare neuropathic conditions such as erythromelalgia and paroxysmal extreme pain disorder [3].

The core process involved in the pathogenesis of neuropathic pain involves pathological changes in the somatosensory nervous system that lead to abnormal changes and disorders of sensory signals into the spinal cord and brain [4]. Besides nerve injury, a 
number of potential predisposing factors before and after the formation of a lesion can contribute to the manifestation of chronic pain, including age, gender difference, pain sensitivity, emotional disorders and cognitive impairment [5]. According to sensory classification, neuropathic pain can be divided into three types: ongoing pain, paraesthesias, and altered stimulus-response function, including allodynia (pain in response to a nonnociceptive stimulus), hyperalgesia (an increased pain sensitivity to a nociceptive stimulus), and loss of sensation in some areas. These factors predominantly manifest as burning pain, paroxysmal electric shock-like pain, and brush-evoked pain [6,7]. Trauma (surgery, amputation), metabolic disorders (diabetes, uremia), infection (herpes zoster, HIV), poisoning (chemotherapy), vascular disease (arteritis nodosa), and malnutrition are all considered to be factors related to the initiation of neuropathic pain.

A previous study reported that $17 \%$ of patients experiencing neuropathic pain in the UK considered their quality of life to be 'worse than death' [8]. As the global population ages, the incidence of neuropathic pain associated with diabetes and cancer survival will inevitably become more common [9]. Numerous patients suffer from moderate or severe pain for many years. It is very difficult to cure patients with such pain; only $40-60 \%$ of pain symptoms can be partially relieved $[2,10]$. The current analgesics that are used to treat neuropathic pain have emerged from neurology or psychiatry, such as antiepileptics (pregabalin) and tricyclic antidepressants (amitriptyline). And for antiepileptics, they are expected to be effective in the treatment of neuropathic pain since epilepsy and neuropathic pain share the same pathophysiology, namely neural hyperexcitability; in addition, drug repurposing is a growing practice in human medicine. Unfortunately, these drugs are often ineffective or induce intolerable side effects or withdrawal reactions [11]. Thus, we need to look for safer and more effective drugs, and it is convenient to access natural products compared with synthetic drugs, owing to the diversity of functional secondary metabolites. Natural products, especially plant secondary metabolites are important options for treating different pain conditions, such as alkaloids, flavonoids and glycosides [2,12-14]. As for glycosides, they are ubiquitous natural products, and due to their structural diversity, especially the aglycone part, they have numerous pharmacological activities, such as antinociceptive, neuroprotective, antioxidant and anti-inflammatory effects $[15,16]$. Evidence also suggests that glycosides can achieve a positive antinociceptive effect on neuropathic pain [17].

In this review, we selected 11 glycosides with more clear mechanisms and summarized their antinociceptive effects on neuropathic pain. The aim of this review is to provide a theoretical basis for a preclinical study for drug research and development, and then facilitate the discovery of drugs for the treatment of neuropathic pain.

\section{Epidemiology of Neuropathic Pain}

According to a recent systematic review and meta-analysis, approximately $18 \%$ of the general population in developing countries experience chronic pain [18]. In addition to adults, chronic pain is known to affect $11-38 \%$ of adolescents and approximately $3-5 \%$ of these patients report severe disability from it [19-21].

Due to the lack of diagnostic criteria for neuropathic pain in epidemiological studies at the population level, it is difficult to evaluate the true prevalence and/or incidence of it [9]. Moreover, most previous studies have focused on certain etiological conditions, such as trigeminal neuralgia, painful diabetic peripheral neuropathy, postherpetic neuralgia, cancer, and viruses $[22,23]$. Studies have shown that the incidence of neuropathic pain is related to gender, age, education, employment, the inhabited environment, and the socioeconomic level. Moreover, the incidence of pain is high in women, elderly people, those with less formal education, physical laborers, rural residents, and people of a low socio-economic level $[19,24,25]$. The prevalence of neuropathic pain in patients with trigeminal neuralgia is three times higher in women than in men (ranging from 0.03-0.3\%) and has a significant impact on people aged 37-67 years [22]. 
A recent systematic review reported that the best estimate for the prevalence of neuropathic pain may be $6.9-10 \%$ in the general population [23]. In the U.S.A, one third of Americans suffer from chronic pain; this exceeds the sum of cases afflicted by heart disease, cancer, and diabetes. Moreover, approximately one fifth of patients with chronic pain are considered to have neuropathic pain [26,27]. The prevalence of neuropathic pain in the U.S.A. is similar to that in other industrialized countries; the prevalence in Canada and the UK was reported to be 7.7\% [28] and 8\% [26], respectively. Neuropathic pain is often associated with a specific condition, such as diabetes, traumatic brachial plexus injury, bone metastases, sickle cell disease, and advanced cancer; the prevalence of neuropathic pain for these diseases has been reported to be $50 \%, 56 \%, 25.8 \%, 20-25 \%$ and $30.6 \%$, respectively [29-33]. It is important that clinicians consider the existence of neuropathic pain characteristics when treating patients so as to optimize patient care and the management of symptoms.

Recent research shows that one of the most common symptoms of coronavirus disease 2019 (COVID-19) is pain [34]. Patients with chronic pain who are infected with severe acute respiratory syndrome coronavirus 2 (SARS-CoV-2) might experience the aggravation of symptoms or the deterioration of the nervous system [35]. Neurological complications that are associated with coronaviruses (for example, Guillain-Barre syndrome and chronic inflammatory demyelinating polyneuropathy) are at risk of developing peripheral neuropathic pain. SARS-CoV-2 often invades the nervous system directly or via post-viral immune reactions and then causes peripheral or central neurological complications. As a consequence, a patient may develop COVID-19-induced neuropathic pain due to neurological complications [36]. As many as $2.3 \%$ of inpatients with COVID-19 have reported potential neuropathic pain. In fact, since chronic pain usually occurs within a few months after nerve injury, the true prevalence may easily be underestimated [35].

\section{Pharmacological Treatment of Neuropathic Pain}

At present, the main clinical modality used to treat neuropathic pain is drug therapy [37]. Finnerup et al. carried out a systematic review and meta-analysis for the pharmacotherapy of neuropathic pain by considering the Grading of Recommendations Assessment, Development, and Evaluation (GRADE) guidelines and recommendations put forward by the Special Interest Group on Neuropathic Pain (NeuPSIG). This analysis revealed that tricyclic antidepressants, serotonin-noradrenaline reuptake inhibitors, pregabalin, and gabapentin were strongly recommended as the first-line treatment for neuropathic pain. Weaker recommendations were also reported for a range of second-line drugs, including lidocaine patches, high concentration capsaicin patches, and tramadol. A number of third-line drugs were also recommended, including strong opioids and botulinum toxin A, although topical agents and botulinum toxin A were only recommended for peripheral neuropathic pain. This study also provided strong recommendations against the use of levetiracetam and mexiletine [38] (Table 1).

Boyle et al. explored the antinociceptive effect of amitriptyline, pregabalin, and duloxetine on patients with painful diabetic neuropathy; analyses showed that all of the medications tested reduced pain when compared with placebo, but no one treatment was superior to any other. Subjective pain ratings (BPI severity) showed improvements of approximately $50 \%$; this was in line with previous research [39]. Another study showed that in patients with localized neuropathic pain (LNP) who treated with a $5 \%$ lidocaine patch and placebo for three months, dynamic mechanical allodynia diminished progressively by $\geq 30 \%$ in $96 \%$ of patients and by $\geq 50 \%$ in $83 \%$ of patients, and cold pain and maximal mechanical pain thresholds improved [40]. Although some drugs have targeted mechanism research, there are still some analgesics which are symptomatic and lack an in-depth study of underlying pain mechanisms. Consequently, these drugs provide a brief respite from pain and are only effective for a few patients. Generally, most of these drugs exhibit side effects that limit their clinical application [39], such as dizziness [41], cardiotoxicity [42], erythema [42], addiction [43], and respiratory depression [44]. Therefore, the research and 
development of new drugs against neuropathic pain that act in a more targeted and safer manner has become a significant hotspot in pain research.

Table 1. Recommended drugs for the treatment of neuropathic pain based on the GRADE classification.

\begin{tabular}{|c|c|c|c|c|}
\hline Grade & Drug & $\begin{array}{l}\text { Neuropathic Pain } \\
\text { Conditions }\end{array}$ & Major Side-Effects & $\begin{array}{c}\text { Strength of } \\
\text { Recommendation }\end{array}$ \\
\hline \multicolumn{5}{|c|}{ First-line drug } \\
\hline & $\begin{array}{l}\text { Serotonin-noradrenaline reuptake } \\
\text { inhibitors duloxetine and } \\
\text { venlafaxine }\end{array}$ & All & Nausea & Strong \\
\hline & Tricyclic antidepressants & All & $\begin{array}{c}\text { Sedation, } \\
\text { anticholinergic effects }\end{array}$ & Strong \\
\hline & $\begin{array}{l}\text { Pregabalin, gabapentin, gabapentin } \\
\text { extended release or enacarbil }\end{array}$ & All & $\begin{array}{l}\text { Sedation, dizziness, } \\
\text { peripheral oedema }\end{array}$ & Strong \\
\hline \multicolumn{5}{|c|}{ Second-line drug } \\
\hline & Tramadol & All & $\begin{array}{l}\text { Nausea/vomiting, } \\
\text { constipation, } \\
\text { dizziness }\end{array}$ & Weak \\
\hline & Capsaicin $8 \%$ patches & Peripheral & $\begin{array}{l}\text { local pain, oedema, } \\
\text { and erythema }\end{array}$ & Weak \\
\hline & Lidocaine patches & Peripheral & Local erythema, rash & Weak \\
\hline \multicolumn{5}{|c|}{ Third-line drug } \\
\hline & Strong opioids & All & $\begin{array}{l}\text { Nausea/vomiting, } \\
\text { constipation, } \\
\text { dizziness }\end{array}$ & Weak \\
\hline & Botulinum toxin A & Peripheral & local pain & Weak \\
\hline
\end{tabular}

Natural products are important resources for the development of innovative drugs. Statistical analysis shows that only $36 \%$ of the 1073 new chemical molecular entities produced between 1981 and 2010 involved pure synthesis; rather, more than half came from natural products. Many compounds were found in higher plants between January 1981 and September 2006; indeed, $28 \%$ of new drugs were derived from natural products and their derivatives. Of these, natural compounds from plants have become indispensable modern drugs [45]. For example, vincristine is an anticancer drug derived from Catharanthus roseus (L.) G. Don [46,47], while artemisinin is an important antimalarial drug and a potential anticancer drug that is derived from Artemisia annua L. [48]. The multi-component and multi-target characteristics of medicinal plants can significantly improve their therapeutic effects; it is more convenient and efficient for medicinal plants components in the process of drug discovery and screening compared with synthetic drugs; more and more researchers are now focusing on the efficacy of plant components extracted from various traditional medical systems, such as alkaloids, flavonoids and glycosides; Therefore, researchers tend to look for components with a antinociceptive effect on neuropathic pain from natural products $[7,17,49]$.

\section{Synopsis of Glycosides}

Glycosides are formed by connections between saccharide groups and non-saccharide substances via the terminal carbon atoms of sugar. Glycosides are the secondary metabolites of plants and are associated with a bitter taste [50]. Further modification of the glycosides (for example, by acylation, oxidation, and degradation) has further expanded the structural and functional diversity of metabolites [51]. Structurally, most glycosides are acetals that are formed by dehydration and condensation of the hemiacetal hydroxyl group of saccharides and the hydroxyl group of aglycone (the non-sugar portion). The formation of a bond that connects aglycone to a sugar atom is referred to as a glycosidic bond. Differences between glycoside bonds allow us to divide the glycosides into $\mathrm{N}$-glycoside, $\mathrm{O}$-glycoside 
(which is the most common and abundant), S-glycoside, and C-glycoside. Although some glycosides are simply linked with sugars to increase their transport in vivo, some large glycosides feature aglycones that are modified by complex oligosaccharides; these have special functions that are generated by the synergistic effect of aglycones and sugars [52] (Table 2). Glycosides are widely distributed in nature and are the active ingredients of many Chinese herbal medicines. Furthermore, glycosides can be distributed in all parts of plant anatomy, especially the roots and rhizomes. For example, Panax notoginseng (Burkill) F. H. Chen ex C. H. is known to have the highest content of saponins in its roots and rhizomes [53]. Glycosides have multiple pharmacological activities; for example, vitexin is one of the main components of hawthorn and exerts antinociceptive, anti-tumor, antihypertensive, anti-inflammatory, and antispasmodic effects [54]. Saikosaponin is the main chemical component of Radix Bupleuri and exerts effects against neuropathic pain, along with anti-inflammatory, immunomodulatory, antibacterial, and antiviral effects [55]. In one hand, glycosides' multiple pharmacological activities related to their structure-activity relationships [56]. For antinociceptive activity, removal of hydroxyl groups from glycoside ligands, hydroxyl methylation, elimination of phenylacryloyl or phenylethyl will reduce the antinociceptive effect, and antioxidant activity is determined by the number of unsaturated bonds, the number and location of phenolic hydroxyl groups and carbon chain length [57]. In another hand, glycosides have the characteristics of multiple targets and multiple mechanisms, including the paeoniflorin regulating p38 MAPK/NF- $\mathrm{kB}$ signaling pathway and anti-insulin resistance via LKB1/AMPK and AKT pathways [58,59]; salidroside has an antinociceptive effect via regulating the activation of P2X7 receptors and has neuroprotective effects on the PI3K/Akt/TERT signaling pathway $[60,61]$. But whether glycosides' antinociceptive effect can dominate other pharmacological effects remain no article has been reported yet.

Table 2. Structure of several glycosides.
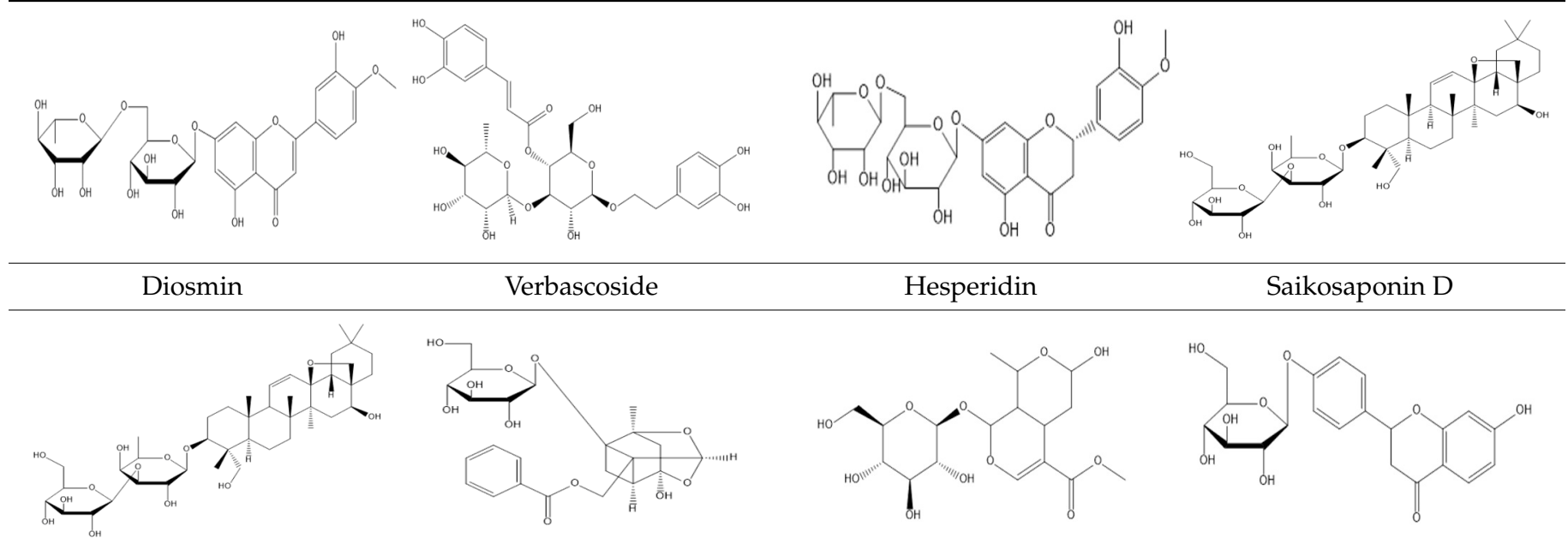

Verbascoside

Hesperidin

Saikosaponin D

Saikosaponin A Paeoniflorin Liquiritin


Many glycosides have an antinociceptive effect; in this review, there are 11 glycosides that are active components of traditional Chinese herbs that have been mentioned because of their clear pharmacological mechanism or significant characteristics (such as local analgesia) or unique chemical structure.

\section{The Antinociceptive Effect of Glycosides in a Rodent Model of Neuropathic Pain}

Clinically, patients with neuropathic pain usually report mechanical and thermal hypersensitivity which can be easily be detected [62]. And the characteristic manifestations of peripheral neuropathic pain in the animal model are basically consistent with the clinical manifestations. The loss of myelinated $A \alpha / \beta$ and $A \delta$ fibers induced by the Wallerian degeneration was shown to produce ipsilateral reflex hyper-responsiveness to mechanical and thermal stimuli in neuropathic pain conditions; A $\beta$-fibers-mediated mechanical hypersensitivity (touch-pressure), C-fibers-mediated thermal hypersensitivity (hot pain) [63].

Allodynia and hyperalgesia are the characteristic manifestations of peripheral neuropathic pain which are the symptoms and signs that may serve as readouts for pain and then contribute to the improved delineation of neuropathic pain, thus providing measures for the structures within the nervous system where signs of neuronal hyperexcitability are present [64]. Clinically meaningful pain reduction is $\geq 30 \%$ reduction in pain from baseline [65]. Allodynia refers to pain in response to a non-nociceptive stimulus; it should only be used when it is known that the test stimulus is not capable of activating nociceptors, such as brush the skin; hyperalgesia refers to increased pain sensitivity, it may include both a decrease in threshold and an increase in suprathreshold response, when we cannot confirm whether or not the test stimulus is capable of acting nociceptors, it is useful to have an umbrella term (hyperalgesia) for all types of increased pain sensitivity [66].

Over the years, a number of laboratory studies have reported associations between glycosides and antinociceptive effect [17]. In the next section of this review, we describe the antinociceptive effect of glycosides on neuropathic pain (Table 3). 
Table 3. Pharmacological activities, behavioral experiment results and mechanisms of glycosides.

\begin{tabular}{|c|c|c|c|c|c|c|c|c|c|c|c|c|c|c|c|c|c|c|c|c|}
\hline \multirow[b]{2}{*}{ Name } & \multirow[b]{2}{*}{$\begin{array}{l}\text { Pharmacological } \\
\text { Activities }\end{array}$} & \multirow[b]{2}{*}{ Animals } & \multirow[b]{2}{*}{ Model } & \multirow[b]{2}{*}{$\begin{array}{c}\text { Dose } \\
\text { mogkg } \\
\text { (Route of } \\
\text { Adminis- } \\
\text { tration) }\end{array}$} & \multicolumn{14}{|c|}{ Nociceptive Tests } & \multirow{2}{*}{ Mechanism } & \multirow{2}{*}{ Refences } \\
\hline & & & & & $\begin{array}{c}\text { Randall- } \\
\text { Selitto } \\
\text { Paw } \\
\text { Pressure } \\
\text { Test } \\
\end{array}$ & $\begin{array}{c}\text { Von Frey } \\
\text { Filament } \\
\text { Test }\end{array}$ & $\begin{array}{l}\text { Radiant } \\
\text { Heat Test }\end{array}$ & $\begin{array}{c}\text { Hot Plate } \\
\text { Test }\end{array}$ & $\begin{array}{l}\text { Tail Im- } \\
\text { mersion } \\
\text { Test }\end{array}$ & $\begin{array}{l}\text { Acetone } \\
\text { Drop Test }\end{array}$ & $\begin{array}{l}\text { Cold } \\
\text { Plate } \\
\text { Test }\end{array}$ & $\begin{array}{c}\text { Rotarod } \\
\text { Test }\end{array}$ & $\begin{array}{c}\text { Spontaneous } \\
\text { Exploratory } \\
\text { Test }\end{array}$ & $\begin{array}{c}\text { Walking } \\
\text { Test }\end{array}$ & $\begin{array}{l}\text { Open- } \\
\text { Field } \\
\text { Test }\end{array}$ & $\begin{array}{c}\text { Elevated } \\
\text { Plus Maze } \\
\text { Test }\end{array}$ & $\begin{array}{c}\text { Forced } \\
\text { Swim } \\
\text { Test }\end{array}$ & $\begin{array}{l}\text { Electrophysiology } \\
\text { Examination }\end{array}$ & & \\
\hline \multirow[b]{2}{*}{ Diosmin } & \multirow[b]{2}{*}{$\begin{array}{c}\text { Antinociceptive, } \\
\text { anti- } \\
\text { inflammatory }\end{array}$} & $\begin{array}{c}\text { Male } \\
\text { Wistar } \\
\text { rats }\end{array}$ & CCI & $\begin{array}{c}10,100, \\
316.2, \\
52.3 \\
\text { or } 1000 \\
\text { mg } / \mathrm{kg}, \\
\text { i.p. }\end{array}$ & - & $\begin{array}{l}\downarrow \text { Mechani- } \\
\text { cal } \\
\text { cyperalge- } \\
\text { sia }\end{array}$ & $\begin{array}{c}\downarrow \text { Thermal } \\
\text { hyperalge- } \\
\text { sia }\end{array}$ & & - & & - & & & & $\begin{array}{l}\overrightarrow{ } \\
\text { Loco- } \\
\text { motor } \\
\text { activity }\end{array}$ & & & - & $\begin{array}{c}\downarrow \text { pro- } \\
\text { inflammatory } \\
\text { cytokines } \\
\text { released }\end{array}$ & [67] \\
\hline & & $\begin{array}{c}\text { Male } \\
\text { Swiss } \\
\text { mice }\end{array}$ & CCI & $\begin{array}{c}10 \mathrm{mg} / \mathrm{kg} \\
\text { i.p. }\end{array}$ & - & $\begin{array}{l}\downarrow \text { Mechani- } \\
\text { cal } \\
\text { hyperalge- } \\
\text { sia }\end{array}$ & - & $\begin{array}{l}\begin{array}{l}\downarrow \text { Thermal } \\
\text { hyperalge- } \\
\text { sia }\end{array}\end{array}$ & - & & - & & & & - & & & - & $\begin{array}{c}\uparrow \\
\text { NO//GMP/PKG/ } \\
\text { KATP channel } \\
\text { signaling } \\
\text { pathway, } \\
\downarrow \text { pro- } \\
\text { inflammatory } \\
\text { cytokines } \\
\text { released }\end{array}$ & [68] \\
\hline Verbascoside & $\begin{array}{l}\text { Antinociceptive, } \\
\text { Antioxidant, }\end{array}$ & $\begin{array}{c}\text { Adult } \\
\text { male } \\
\text { Wistar } \\
\text { rats } \\
\end{array}$ & CCI & $\begin{array}{l}50,100, \\
\text { and } 200, \\
\text { m/kg, } \\
\text { i.p. }\end{array}$ & & $\begin{array}{c}\downarrow \text { mechani- } \\
\text { cal } \\
\text { allodynia }\end{array}$ & $\begin{array}{c}\downarrow \text { heat } \\
\text { hyperalgesia }\end{array}$ & & & $\begin{array}{l}\downarrow \text { cold } \\
\text { allodynia }\end{array}$ & & & & & & & & & $\downarrow$ Oxidative stress & [69] \\
\hline \multirow{3}{*}{ Hesperidin } & \multirow{3}{*}{$\begin{array}{l}\text { Antinociceptive, } \\
\text { antidiabetic }\end{array}$} & $\begin{array}{l}\text { Male } \\
\text { SD rats }\end{array}$ & $\mathrm{CCI}$ & $\begin{array}{c}50 \mathrm{mg} / \mathrm{kg} \\
\text { i.p. }\end{array}$ & - & $\begin{array}{l}\downarrow \text { Mechani- } \\
\text { cal } \\
\text { hyperalge- } \\
\text { sia }\end{array}$ & 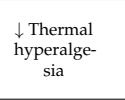 & & - & & - & & & & & & & - & $\downarrow P 2 \times 3$ receptor & [70] \\
\hline & & $\begin{array}{c}\text { Male } \\
\text { Wistar } \\
\text { rats }\end{array}$ & $\mathrm{CCI}$ & $\begin{array}{c}100 \\
\mathrm{~m} / \mathrm{kg} \\
\mathrm{i} / \mathrm{pg}\end{array}$ & - & $\begin{array}{l}\downarrow \text { Mechani- } \\
\text { cal } \\
\text { hyperalge- } \\
\text { sia }\end{array}$ & $\begin{array}{c}\downarrow \text { Thermal } \\
\text { hyperalge- } \\
\text { sia }\end{array}$ & & - & & - & & & & & & & - & $\begin{array}{c}\downarrow \text { Pro- } \\
\text { inflammatory } \\
\text { cytokines } \\
\text { released }\end{array}$ & [71] \\
\hline & & $\begin{array}{l}\text { Adult } \\
\text { SD rats }\end{array}$ & $\begin{array}{l}\text { STZ- } \\
\text { induced } \\
\text { diabetic } \\
\text { neuropathy }\end{array}$ & $\begin{array}{l}\text { Hesperidin: } \\
25,50,100 \\
\text { mg } / \mathrm{kg}, \\
\text { p.o. } \\
\text { Insulin: } 10 \\
\mathrm{IU} / \mathrm{kg}, \mathrm{s.c.}\end{array}$ & $\begin{array}{l}\downarrow \begin{array}{l}\text { Mechani- } \\
\text { cal } \\
\text { hyperalge- } \\
\text { sia }\end{array} \\
\text { sia }\end{array}$ & $\begin{array}{l}\text { Mechano- } \\
\text { tactile } \\
\text { allodynia }\end{array}$ & - & & $\begin{array}{l}\downarrow \text { Thermal } \\
\text { hyperalge- } \\
\text { sia }\end{array}$ & & - & & & & & & & $\begin{array}{l}\uparrow \mathrm{MNCV}, \\
\uparrow \mathrm{SNCV}\end{array}$ & $\begin{array}{c}\downarrow \text { Glycated } \\
\text { hemoglobin, AR } \\
\text { activity, } \\
\text { oxidonitrosative } \\
\text { stress, neural } \\
\text { calcium, and pro- } \\
\text { inflammatory } \\
\text { cytokines } \\
\end{array}$ & [72] \\
\hline $\begin{array}{l}\text { Saikosaponin } \\
\text { D }\end{array}$ & Antinociceptive & $\begin{array}{l}\text { Male } \\
\text { ICR } \\
\text { mice }\end{array}$ & $\begin{array}{c}\text { VCR- } \\
\text { induced } \\
\text { neuro- } \\
\text { pathic } \\
\text { pain }\end{array}$ & $\begin{array}{l}5,20 \\
\text { mg/kg } \\
\text { i.p. }\end{array}$ & - & $\begin{array}{l}\downarrow \text { Mechani- } \\
\text { cal } \\
\text { hypersen- } \\
\text { sitivity }\end{array}$ & - & - & - & - & - & & & & - & & & - & $\begin{array}{l}\downarrow \text { Activation of } \\
\text { TRPA1 channel }\end{array}$ & [73] \\
\hline$\underset{\mathrm{A}}{\text { Saikosaponin }}$ & $\begin{array}{c}\text { Antinociceptive, } \\
\text { anti- } \\
\text { inflammatory }\end{array}$ & $\begin{array}{l}\text { Adult } \\
\text { SD rats }\end{array}$ & CCI & $\begin{array}{c}6.25 \\
12.50 \text { and } \\
25.000 \\
\text { mog/kg, } \\
\text { i.p. }\end{array}$ & - & $\begin{array}{l}\downarrow \text { Mechani- } \\
\text { cal } \\
\text { allodynia }\end{array}$ & 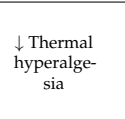 & - & - & - & - & & & & - & & & - & $\begin{array}{c}\downarrow \text { Activation of } \\
\text { P38 MAPK and } \\
\text { NF- KB signaling } \\
\text { pathway }\end{array}$ & [55] \\
\hline
\end{tabular}


Table 3. Cont.

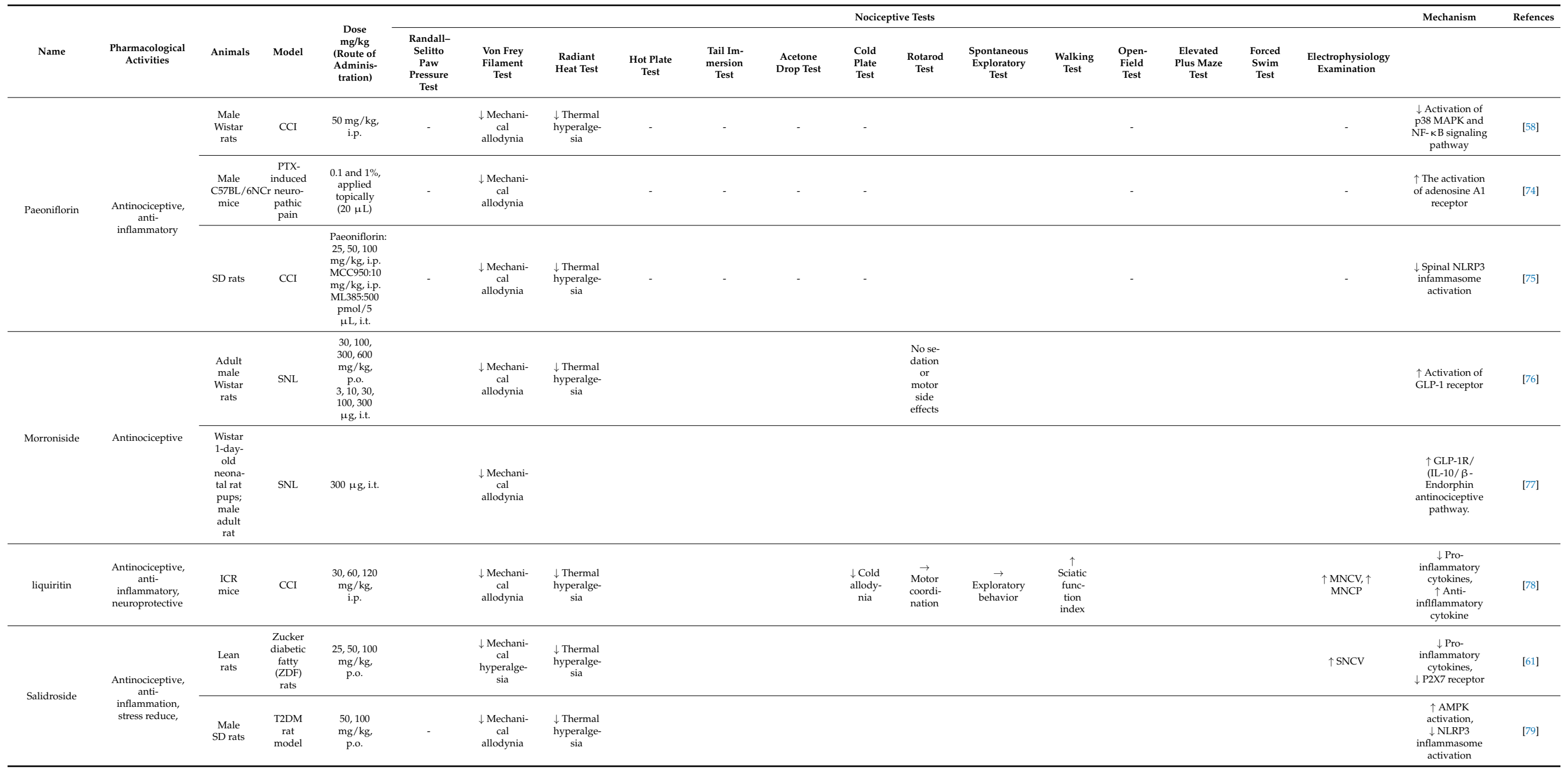


Table 3. Cont.

\begin{tabular}{|c|c|c|c|c|c|c|c|c|c|c|c|c|c|c|c|c|c|c|c|c|}
\hline \multirow[b]{2}{*}{ Name } & \multirow[b]{2}{*}{$\begin{array}{c}\text { Pharmacological } \\
\text { Activities }\end{array}$} & \multirow[b]{2}{*}{ Animals } & \multirow[b]{2}{*}{ Model } & \multirow[b]{2}{*}{$\begin{array}{c}\text { Dose } \\
\text { gh/gkg } \\
\text { (Route of } \\
\text { Adminis- } \\
\text { tration) }\end{array}$} & \multicolumn{14}{|c|}{ Nociceptive Tests } & \multirow[t]{2}{*}{ Mechanism } & \multirow[t]{2}{*}{ Refence. } \\
\hline & & & & & $\begin{array}{c}\text { Randall- } \\
\text { Selitto } \\
\text { Paw } \\
\text { Pressure } \\
\text { Test } \\
\end{array}$ & $\begin{array}{c}\text { Von Frey } \\
\text { Filament } \\
\text { Test }\end{array}$ & $\begin{array}{l}\text { Radiant } \\
\text { Heat Test }\end{array}$ & $\begin{array}{l}\text { Hot Plate } \\
\text { Test }\end{array}$ & $\begin{array}{l}\text { Tail Im- } \\
\text { mersion } \\
\text { Test }\end{array}$ & $\begin{array}{c}\text { Acetone } \\
\text { Drop Test }\end{array}$ & $\begin{array}{l}\text { Cold } \\
\text { Plate } \\
\text { Test }\end{array}$ & $\begin{array}{c}\text { Rotarod } \\
\text { Test }\end{array}$ & $\begin{array}{c}\text { Spontaneous } \\
\text { Exploratory } \\
\text { Test }\end{array}$ & $\begin{array}{l}\text { Walking } \\
\text { Test }\end{array}$ & $\begin{array}{c}\text { Open- } \\
\text { Field } \\
\text { Test }\end{array}$ & $\begin{array}{c}\text { Elevated } \\
\text { Plus Maze } \\
\text { Test }\end{array}$ & $\begin{array}{c}\text { Forced } \\
\text { Swim } \\
\text { Test }\end{array}$ & $\begin{array}{l}\text { Electrophysiology } \\
\text { Examination }\end{array}$ & & \\
\hline Isoorientin & $\begin{array}{l}\text { Antinociceptive, } \\
\text { Antioxidant, }\end{array}$ & $\begin{array}{l}\text { Male } \\
\text { ICR } \\
\text { mice }\end{array}$ & CCI & $\begin{array}{c}7.5,15 \text {, and } \\
30 \\
\mathrm{mg} / \mathrm{kg} / \mathrm{day} \text {, } \\
\text { p.o. }\end{array}$ & - & $\begin{array}{c}\downarrow \text { Mechani- } \\
\text { cal } \\
\text { allodynia }\end{array}$ & 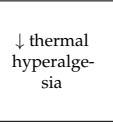 & & - & & $\begin{array}{l}\downarrow \text { cold } \\
\text { allody- } \\
\text { nia }\end{array}$ & & & & & & & $\begin{array}{l}\uparrow \text { SNCV, } \\
\uparrow \text { SNAP }\end{array}$ & $\begin{array}{c}\text { TT-AOC, T-SOD, } \\
\text { CAT, MDA } \\
\downarrow \text { Mro- } \\
\text { inflammatory } \\
\text { cytokines } \\
\end{array}$ & [80] \\
\hline Albiflorin & $\begin{array}{c}\text { Antinociceptive, } \\
\text { anti-anxiety and } \\
\text { anti-depressant } \\
\text { anti- } \\
\text { inflammatory, } \\
\text { neuroprotective, }\end{array}$ & $\begin{array}{c}\text { Adult } \\
\text { male } \\
\text { SD rats }\end{array}$ & CCI & $\begin{array}{c}50 \mathrm{mg} / \mathrm{kg}, \\
\text { i.p. }\end{array}$ & & $\begin{array}{l}\downarrow \text { Mechani- } \\
\text { cal } \\
\text { allodynia }\end{array}$ & & & & & & & & & $\begin{array}{c}\text { Anxiety- } \\
\text { like } \\
\text { behav- } \\
\text { ior }\end{array}$ & $\begin{array}{l}\downarrow \text { Anxiety- } \\
\text { like } \\
\text { behavior }\end{array}$ & $\begin{array}{c}\downarrow \\
\begin{array}{c}\text { Depression- } \\
\text { like } \\
\text { behav- } \\
\text { ior }\end{array} \\
\end{array}$ & & $\begin{array}{c}\downarrow \text { NLRP3 } \\
\text { inflammasome } \\
\text { activity }\end{array}$ & [81] \\
\hline Geniposide & $\begin{array}{l}\text { Antinociceptive, } \\
\text { anti- } \\
\text { inflammatory, }\end{array}$ & $\begin{array}{c}\text { Adult } \\
\text { male } \\
\text { SD rats }\end{array}$ & $\begin{array}{l}\text { STZ- } \\
\text { induced } \\
\text { diabetic } \\
\text { neuropathy }\end{array}$ & $\begin{array}{c}\text { 1, 10, } 100 \\
\text { mg/kg, } \\
\text { i.p. }\end{array}$ & & $\begin{array}{c}\downarrow \text { Mechani- } \\
\text { cal } \\
\text { allodynia }\end{array}$ & & & & & & & & & & & & & $\begin{array}{c}\downarrow \text { Pro- } \\
\text { inflammatory } \\
\text { cytokines, }\end{array}$ & [82] \\
\hline
\end{tabular}

CCI: chronic constriction injury; SD: Sprague-Dawley; PTX: paclitaxel; STZ: streptozotocin; i.p.: intraperitoneal injection; i.t.: Intrathecal injection; p.o.: oral; $\rightarrow:$ Not affect/unchanged; $\uparrow:$ Enhanced/Increased/Upregulate; $\downarrow$ : Attenuate/Downregulate/Decrease/Suppress/Inhibit/Prevent. 


\subsection{Hesperidin}

Hesperidin is isolated from Citrus reticulata Blanco [83]. In recent studies, hesperidin can both applicable in chronic constriction injury (CCI) and streptozotocin (STZ)- induced neuropathic pain rats. Administration of hesperidin $(50 \mathrm{mg} / \mathrm{kg}$ or $100 \mathrm{mg} / \mathrm{kg}$ ) resulted in a relief of mechanical hyperalgesia and thermal hyperalgesia in a CCI-induced neuropathic pain model of rats [70,71]. In another study, hesperidin $(25,50$, and $100 \mathrm{mg} / \mathrm{kg}$ ) was administered to STZ-induced painful diabetic neuropathy rats for four weeks, then lead to a respite in mechanical allodynia and thermal hyperalgesia [72].

To sum up, in addition to relieving neuropathic pain caused by CCI, hesperidin can relieve pain while alleviating the symptoms of diabetes in STZ-induced painful diabetic neuropathy rats; it can indicate improving blood sugar, alleviate nerve injury, and it also shows that the action of the drug is diverse.

\subsection{Saikosaponins}

Saikosaponins are isolated from Bupleurum chinense DC. [84]. A previous study found that the continuous administration of saikosaponin A $(6.25,12.5$ and $25 \mathrm{mg} / \mathrm{kg})$ over 14 days alleviated mechanical allodynia and thermal hyperalgesia in CCI-induced neuropathic pain rats in a dose-dependent manner [55].

Saikosaponin D $(5,20 \mathrm{mg} / \mathrm{kg})$ was also shown to significantly attenuate agonistinduced nociceptive responses and vincristine-induced mechanical hypersensitivity in neuropathic pain mice [73].

However, researchers thought saikosaponin A alleviated neuropathic pain in a dosedependent manner via three doses may inappropriate, it can be described as a dose-effect relationship, whether saikosaponin A alleviates neuropathic pain in a dose-dependent manner needs continued study.

\subsection{Isoorientin}

Isoorientin is isolated from Pueraria lobata (Willd.) Ohw $i$ [85], Phyllostachys heterocycla (Carr.), Mitford cv. Pubescens [86], and Gentiana scabra Bunge [87]. Researchers have shown that the intragastric administration of isoorientin $(7.5,15$ and $30 \mathrm{mg} / \mathrm{kg}$ ) over eight days alleviated CCI-induced mechanical allodynia, cold allodynia, and thermal hyperalgesia of mice [61]. These authors also observed that the administration of isoorientin also relieved tissue damage such as disordered myelinated nerve fibers, swollen axons, neuron gaps, and unmyelinated axons of the sciatic nerve trunk, as determined by hematoxylin-eosin (H\&E) staining and transmission electron microscopy [80].

As usual, there are a variety of experimental methods to explore the antinociceptive effect of drugs on neuropathic pain. In addition to behavioral experiments, there are histopathological staining experiments to study the neuroprotective effect of drugs, such as H\&E staining to observe the relief of sciatic nerve fiber injury (nerve fiber rupture and neuron vacuole and so on) after administration, and transmission electron microscopy to observe the submicroscopic structure of nerve fibers and understand the changes of the myelin sheath.

\subsection{Liquiritin}

Liquiritin is isolated from the roots of Glycyrrhiza uralensis Fish [88,89]. A previous study showed that CCI-induced neuropathic pain mice were administration of liquiritin $(30,60$, and $120 \mathrm{mg} / \mathrm{kg}$, i.p.) for 8 consecutive days, meanwhile, mice were tested from 7-14 days post-surgery with the Von Frey Filament test, the cold-plate test, and the radiant heat test, then researchers observed that liquiritin could reduce mechanical allodynia, thermal hyperalgesia and cold allodynia [78].

In addition to the analgesic effect of glycyrrhizin on CCI-induced neuropathic pain, recent studies have reported that liquiritin can inhibit SARS-CoV-2 by mimicking type 1 interferon [90]; thus, perhaps liquiritin can alleviate the symptoms of neuropathic pain caused by COVID-19. 


\subsection{Albiflorin}

Albiflorin is isolated from Radix paeoniae Alba [91]. Albiflorin is transformed to benzoic acid in the intestine, a vital metabolite that can cross the blood-brain barrier, improve brain function, and exhibit antidepressant activity [92]. The administration of albiflorin $50 \mathrm{mg} / \mathrm{kg}$ and MCC950 (a selective inhibitor of the NOD-like receptor protein 3 (NLRP3) inflammasome) at a dose of $10 \mathrm{mg} / \mathrm{kg}$ for 15 days led to a number of improvements thereafter, including the alleviation of CCI-induced mechanical allodynia, comorbid anxiety, and depression-like behavior, as determined by the Von Frey test, the open field test, the elevated plus maze test, and the forced swim test [81].

Neuropathic pain is usually accompanied by anxiety and depression, so drugs usually require not only antinociceptive effect but anti-anxiety and anti-depressant activities, and albiflorin just meets the above conditions, so it may be a promising analgesic.

\subsection{Salidroside}

Salidroside is the main active component extracted from Rhodiola rosea L. [60]. A previous study investigated a model of painful diabetic neuropathy, the Zucker diabetic fatty (ZDF) rat which widely used as a model for human diabetes and its complications, including neuropathic pain were given salidroside $(25,50$, and $100 \mathrm{mg} / \mathrm{kg})$ and then observed, and the authors found that the administration of salidroside $(25 \mathrm{mg} / \mathrm{kg}$ and $50 \mathrm{mg} / \mathrm{kg}$ ) showed a partial recovery from allodynia during the 5th week of the experiment and relieved thermal hyperalgesia by the fifth and eighth week, respectively; however, there were no significant improvements in the $100 \mathrm{mg} / \mathrm{kg}$ group [61,93,94]. Another study administered salidroside $(50 \mathrm{mg} / \mathrm{kg} /$ day and $100 \mathrm{mg} / \mathrm{kg} /$ day) to STZ-induced type 2 diabetic rats (that had been fed on a HFD for 4 weeks) for six weeks; analysis showed that both mechanical allodynia and thermal hyperalgesia were alleviated. Analysis also showed that salidroside relieved type 2 diabetes mellitus (T2DM) by improving hyperglycemia and by ameliorating insulin resistance [79]; these results were critical because T2DM is characterized by hyperglycemia and insulin resistance [95].

Interestingly, models of painful diabetic neuropathy, salidroside at a dose of $100 \mathrm{mg} / \mathrm{kg}$ did not have significant antinociceptive effect to neuropathic pain in ZDF rats, but salidroside $100 \mathrm{mg} / \mathrm{kg}$ could relieve STZ-induced mechanical allodynia and thermal hyperalgesia; the reasons for this need to be explored further.

\subsection{Morroniside}

Morroniside is isolated from the dry ripe sarcocarp of Cornus officinalis Sieb. et Zucc. [96], and the leaves of Sarracenia purpurea L. [97]. Morroniside (30, 100, 300, $600 \mathrm{mg} / \mathrm{kg}$, p.o. or $3,10,30,100,300 \mu \mathrm{g}$ i.t.) has been shown to significantly relieve mechanical allodynia and thermal hyperalgesia in spinal nerve ligation (SNL)- induced neuropathic pain in rats in a timeand dose-dependent manner [76,77]. Furthermore, the rotarod test was used to demonstrate that the antinociceptive effect of morroniside was not due to a false positive reaction caused by sedation and had no adverse effect on motor function. To test the analgesic tolerance of morroniside, repeated daily intrathecal injections of morroniside $(100 \mu \mathrm{g})$ in SNL-induced neuropathic pain in rats for seven days increased paw withdrawal thresholds in the ipsilateral paws by $58 \%$ and the significant mechanical antiallodynic effect could persisted for the seven days [76].

Morroniside has a significant antinociceptive effect on neuropathic pain; repeated daily injections of morroniside did not induce antinociceptive tolerance, which is its significant advantage, so it is a potential and promising compound for neuropathic pain.

\subsection{Verbascoside}

Verbascoside is extracted from the leaves of Penstemon barbatus (Cav.) Roth [98], Lippia citriodora H.B.K. [99], and Paulownia tomentosa Steud [100]. Mass spectrometry further showed that caffeic acid was the main metabolite of verbascoside. Verbascoside is known to be apower scavenger for reactive oxygen species (ROS) and can also act as 
an antioxidant agent [101]. In a previous study, Verbascoside (50, 100 and $200 \mathrm{mg} / \mathrm{kg}$ ) was administered intraperitoneally for 14 days continuously from the day of surgery in CCI-induced neuropathic pain rats could alleviate mechanical allodynia, cold allodynia, and heat hyperalgesia, verbascoside was shown to significantly attenuate these behavioral changes associated with neuropathy [69]. In another study, Isacchi et al. found that verbascoside $(100,300,600 \mathrm{mg} / \mathrm{kg})$ reversed mechanical hyperalgesia in CCI- or intraarticular injection of sodium monoiodoacetate (MIA)-induced neuropathic pain rats as determined by the paw pressure test [99].

Verbascoside has a significant antinociceptive effect, but higher water solubility of verbascoside could lead to low bioavailability of this compound. Derivatives of verbascoside and new formulations with more penetration to lipophilic vehicles could help to reduce the effective doses of this agent.

\subsection{Paeoniflorin}

Paeoniflorin is a major active compound isolated from the root of Paeonia lactiflora Pall [102-104]. In PTX (paclitaxel)-induced neuropathic pain mice, Andoh et al. administered a single intraperitoneal injection of PTX followed by the topical administration of paeoniflorin $(0.1 \%$ and $1 \% ; 20 \mu \mathrm{L})$ to the left or both planar surfaces twice daily for 13 days, then observed that the PTX-induced mechanical allodynia was significantly inhibited, but a single administration of paeoniflorin was invalid. They also demonstrated that paeoniflorin exhibited local inhibitory activity. Paeoniflorin (1\%) was applied repeatedly on left plantar surfaces for 13 days after PTX injection; the authors reported that the mechanical allodynia was only relieved in the treated paw [74]. Other studies, investigating CCI-induced neuropathic pain in rats, administered paeoniflorin $(25,50,100 \mathrm{mg} / \mathrm{kg})$ for 11 days continuously after surgery, and ethological analyses demonstrated that paeoniflorin significantly increased the mechanical withdrawal threshold and thermal withdrawal latency on days one, three, seven, and $11[58,75]$.

The local antinociceptive effect of paeoniflorin is a significant characteristic, as generally the adverse reactions of local medication are less than those of systemic medication. Thus, if paeoniflorin can enter the market, it may have significant development prospects.

\subsection{Diosmin}

Diosmin (diosmetin-7-O-rutinoside) is isolated from Scrophularia nodosa and can be obtained via hesperidin dehydrogenation [105]. In CCI-induced neuropathic pain rats, diosmin $(10,100,316.2,562.3$, and $1000 \mathrm{mg} / \mathrm{kg})$ could attenuate mechanical and thermal hyperalgesia in acute treatments (0-120 min) except $10 \mathrm{mg} / \mathrm{kg}$, and diosmin $(316.2 \mathrm{mg} / \mathrm{kg})$ could also attenuate mechanical and thermal hyperalgesia in sub-chronic (15-28 days) treatments, ultra-high-performance liquid chromatography tandem mass spectrometry (UHPLC-MS) analysis further found that diosmin could cross the blood brain barrier [67]. Another study showed that mice withCCI-induced neuropathic painthat received a single administrated diosmin $(1,10 \mathrm{mg} / \mathrm{kg})$ at the seventh day or received prolonged administration of diosmin $(10 \mathrm{mg} / \mathrm{kg})$ at the $7 \mathrm{th}-14$ th days exhibited inhibited mechanical and thermal hyperalgesia, and they also demonstrated long term application of diosmin do not causing gastric leision or renal damage [68].

In conclusion, long-term and short-term administration of diosmin can alleviate the symptoms of neuropathic pain, at the same time, it also shows that long-term administration of diosmin may have no tolerance.

\subsection{Geniposide}

Geniposide is isolated from Gardenia jasminoides Ellis [106]. Studies show that geniposide produces antinociception during persistent pain [107]. In a streptozotocin (STZ)induced painful diabetic neuropathy model of SD rats, geniposide $(1,10$ and $100 \mathrm{mg} / \mathrm{kg})$ was administered intraperitoneally for seven days continuously from the 21 st day after 
modeling, then researchers found geniposide could alleviate mechanical hyperalgesia in addition to reducing blood glucose in diabetic neuropathy SD rats [82].

Studies have shown that the iridoid structure represented by geniposide analogs is a novel core structure for activating glucagon-like peptide- 1 receptors (GLP-1Rs, recently discovered pain receptors); thus, the study of geniposide may lay a foundation for the development of new neuropathic pain analgesics targeting GLP-1R.

Collectively, these eleven glycosides have significant antinociceptive effects in preclinical pharmacological experiments, and have potential as therapeutic agents for neuropathic pain.

\section{Antinociceptive Mechanisms Underlying the Action of Glycosides on Neuropathic Pain}

Mechanism-based treatment is closely related to disease/cause-based treatments. By knowing how certain diseases (e.g., diabetes) or other factors cause (e.g., oxaliplatin) neuropathic pain, we can use a further mechanism-based approach to obtain optimal analgesics. A number of studies have shown that glycosides are involved in multiple peripheral mechanisms of neuropathic pain, as described in the following section.

\subsection{Glycosides and Oxidative Stress}

Oxidative stress and inflammation have been proposed to play both causative and deteriorative roles in neuropathic pain. Elevated levels of ROS have been detected at sites of inflammation and tissue injury [108]. Matrix metalloproteinases (MMPs) are responsible for neuropathic pain; previous research has shown that MMP-9 is correlated with oxidative stress and the activation of glial cells $[109,110]$. Peripheral nerve injury is known to elevate ROS levels; in turn, ROS activates MMP-9 and then activates cytokines, including IL- $1 \beta$. These cytokines act on adjacent microglia and astrocytes, which then release pain-causing substances such as pro-inflammatory cytokines. Subsequently, these pro-inflammatory cytokines can activate activated glial cells and neurons via positive feedback loop mechanisms. Collectively, these processes enhance peripheral and central sensitization to maintain neuropathic pain [111-113]. In a model of CCI-induced neuropathic pain, the administration of isoorientin was shown to alleviate oxidative stress by influencing markers of oxidative stress, including total antioxidant capacity (T-AOC), catalase (CAT), and total superoxide dismutase (T-SOD). These changes increased malondialdehyde (MAD), thus leading to the expression of MMP-9; this significantly reduced oxidative stress and inflammation and the activation of microglia and astrocytes, thus reducing the expression levels of proinflammatory cytokines. Therefore, isoorentin plays an antinociceptive role in neuropathic pain by inhibiting oxidative stress, the activation of MMP-9, and neuroinflammation [80].

\subsection{Glycosides and Transcriptional Regulation}

\subsubsection{Glycosides and Pro-Inflammatory Cytokines}

Over recent years, research has repeatedly emphasized the importance of the neuroinflammatory response in the development and maintenance of inflammatory and neuropathic pain. The inflammatory cells that cause this reaction include circulating immune cells, such as monocytes, $\mathrm{T}$ and $\mathrm{B}$ lymphocytes, neutrophils, and glia in the central nervous system. Pain signals are transmitted by sensory neurons in the peripheral nervous system. These neurons express different receptors and ion channels and respond to mediators secreted by these inflammatory cells [114]. Pro-inflammatory cytokines are involved in demyelination and the degeneration of peripheral nerves and can also increase the excitability of sensory afferents, thus inducing neuropathic pain [115].

In vivo, saikosaponin A can significantly reduce the levesl of TNF- $\alpha$, IL-1 $\beta$, and IL-2 protein expression, along with $p-p 38$ and nuclear factor kappa $B$ (NF- $\kappa B$ ) mRNA and protein expression levels in the spinal cord, so as to exert an antinociceptive effect on neuropathic pain [55]. Hesperidin, diosmin and liquiritin are also known to regulate pro-inflammatory cytokines (IL-1 $\beta$, IL- 6 , and TNF- $\alpha$ ) in a mouse model of CCI-induced neuropathic pain, thereby alleviating mechanical and thermal hyperalgesia [71,78]. In an STZ-induced model of painful diabetic neuropathy, the co-administration of hesperidin $(100 \mathrm{mg} / \mathrm{kg}$; per os) 
and insulin $10 \mathrm{IU} / \mathrm{kg}$ (subcutaneous injection) was shown to play a synergistic effect; the highest antinociceptive activity occurred by controlling hyperglycemia and downregulating hyperlipidemia to down-regulate the generation of free radicals, the release of pro-inflammatory cytokines, and the elevation of membrane bound enzymes to reverse mechanical and thermal hyperalgesia [72] (Figure 1).

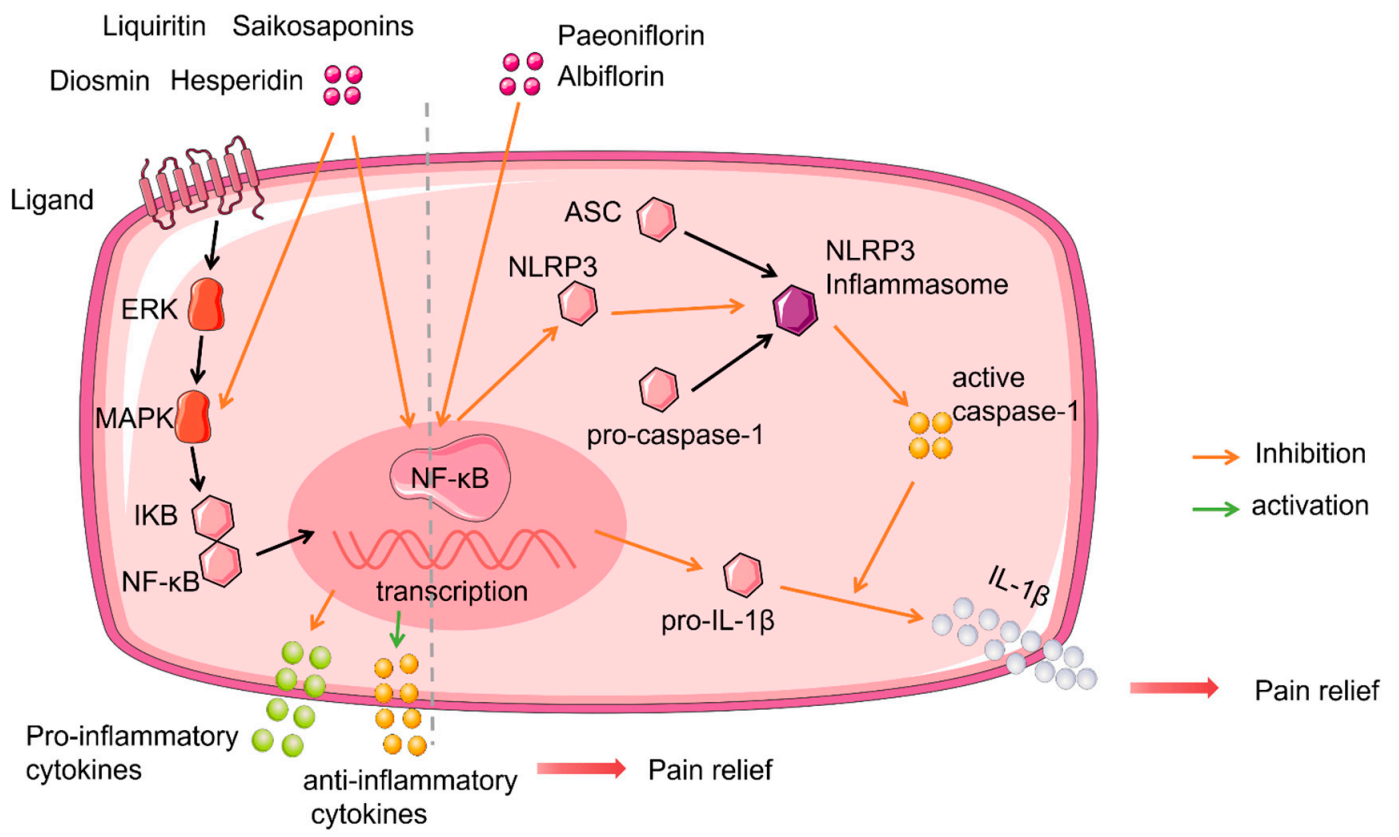

Figure 1. Glycosides and transcriptional regulation. Liquitin, saikosaponins, diosmin and hesperidin produced relief of neuropathic pain via inhibited NF- $\mathrm{B}$ transcription downregulated proinflammatory cytokines, upregulated anti- inflammatory cytokines. Paeoniflorin and albiflorin inhibited NF- $\mathrm{KB}$ transcription and downregulated the transcription levels of inactive NLRP3 and pro-IL-1 $\beta$ contribute to the reduce of NLRP3 inflammasome synthesis, then active caspase- 1 cleaved pro-IL-1 $\beta$, reduced IL-1 $\beta$ released, lead to pain relief.

\subsubsection{Glycosides and the NOD-Like Receptor Protein 3 (NLRP3) Inflammasome}

NLRP3 inflammasome activity is a necessary component of the innate immune response to tissue damage. The dysregulation of inflammasome activity has been implicated in a number of neurological conditions [116]. The NLRP3 inflammasome is composed of NLRP3, adaptor ASC, and caspase-1 enzymes, and can be activated by inflammatory stimuli $[116,117]$. Recent studies have shown that the NLRP3 inflammasome also exists in the neurons of the sensory nervous system and are related to neuropathic pain $[81,118,119]$.

In models of CCI-induced neuropathic pain, paeoniflorin was shown to inhibit NLRP3 and pro-IL-1 $\beta$ by inhibiting the regulation of NF- $k B$-mediated transcription. NLRP3 is the most extensive regulator of Caspase- 1 activation and can produce and activate caspase- 1 , and then cleave pro-IL-1 $\beta$ into mature IL-1 $\beta$. Paeoniflorin can also inhibit the downstream bioactive components caspase- 1 and IL-1 $\beta$, thus inhibiting neuropathic pain. However, after applying a selective inhibitor of NLRP3 (MCC950), the antinociceptive effect and related protein expression of paeoniflorin and MCC950 on neuropathic pain were very similar; this suggested that the antinociceptive effect of paeoniflorin on neuropathic pain occurred by inhibiting the activity of the NLRP3 inflammasome [75]. Glycosides do not only exhibit an antinociceptive effect; they can also alleviate mood disorders. It has been demonstrated that the NLRP3 inflammasome is involved in the pathological processes of anxiety and depression during neuropathic pain conditions. Albiflorin can relieve anxiety and depression-like behavior under neuropathic pain conditions, and these effects are regulated by the Kelch-like ECH associated protein 1 (Keap1)/nuclear factor erythroid 
2-related factor 2 (Nrf2) signaling pathway; these processes reduced antioxidant levels to suppress the hippocampal activation of NLRP3 inflammation [81] (Figure 1).

\subsection{Glycosides and Ion Channels \\ 6.3.1. Glycosides and P2X Receptors}

Adenosine triphosphate (ATP) is a key modulator in nociception mechanisms [120]. P2X receptor 7 (P2X7R) is a plasma membrane receptor that exhibits the lowest sensitivity for extracellular ATP in the P2XR family [121,122]. This high threshold for activation confers a damage-sensing role to $\mathrm{P} 2 \mathrm{X} 7$ as this receptor only triggers downstream effects when the concentration of ATP is pathologically elevated. P2X7R acts as a cell surface regulator for inflammasome recruitment and the synthesis and release of pro-inflammatory cytokines. Previous studies have also shown that multiple inflammatory cascades are involved in neuropathic pain $[122,123]$. The P2X receptor plays an important role in mediating ATP signals to produce and maintain chronic pain; thus, this receptor is considered to be a promising antinociceptive target.

Following the administration of salidroside $(25 \mathrm{mg} / \mathrm{kg}$ and $50 \mathrm{mg} / \mathrm{kg})$ for eight weeks, the levels of P2X7R, TNF- $\alpha$, and IL- $1 \beta$ were significantly reduced in a rat model of painful diabetic neuropathy [61]. In a previous in vitro study, pEGFP-hP2X7 was transfected into HEK293 cells. Then, salidroside was used to inhibit ATP $(100 \mu \mathrm{M})$-activated currents, as monitored by whole cell patch clamping. These data indicated that salidroside could not only down- regulate the expression of the $\mathrm{P} 2 \mathrm{X} 7$ receptor, but it could also directly target and inhibit the P2X7 receptor [61].

\subsubsection{Glycosides and Transient Receptor Potential Ankyrin 1 (TRPA1)}

Members of the transient receptor potential (TRP) channel family are known to be a kind of ion channel and have attracted significant attention in the search for new therapies for neuropathic pain. Members of this broad class of ion channels are involved in a wide range of processes associated with sensory perception, including pernicious chemicals, along with mechanical and thermal sensations [124,125]. Transient receptor potential ankyrin 1 (TRPA1) is a member of the family of TRP channels; specifically, TRPA1 is a nonselective cation channel and is mainly expressed in the neurons of the root ganglion [126]. Studies have shown that the TRPA1 channel, as a major pain transducer, plays a key role in neuropathic pain (especially in the transition from acute pain to chronic pain), and can mediate mechanical hyperalgesia and cold hypersensitivity in the neuropathic pain caused by chemotherapy [127]. Research has demonstrated that cisplatin-induced mechanical hypersensitivity was inhibited by the silencing of TRPA1 expressing afferents [128].

In previous research, high-throughput screening (HPS) demonstrated that saikosaponins which contain glycosyl and aglycone components could inhibit TRPA1, so it is necessary to determine whether the glycosyl component of saikosaponins is required to inhibit TRPA1, then aglycone from saikosaponins such as saikogenins A and D were tested by calcium assays, and results showed that they had no effect on agonist-stimulated calcium flux, thus indicating that there is a requisite role for the active sugar group of saikosaponins [73]. AITC is an agonist of the TRPA1 channel in primary afferent neurons and is known to lead to an acute pain response in rodents. Following the generation of an AITC-induced pain model, researchers found that saikosaponin D $(50 \mathrm{mg} / \mathrm{kg})$ significantly reduces the nociceptive response time by approximately $25 \%$, thus indicating that saikosaponin D could inhibit the activation of TRPA1 induced by AITC in vivo, thus proving that saikosaponin D acts as an antagonist of TRPA1. Studies have shown that TRPA1 is involved in chemotherapy-induced neuropathic pain [129]. Through the establishment of a vincristine-induced model of neuropathic pain, researchers found that saikosaponin D $(20 \mathrm{mg} / \mathrm{kg})$ could significantly alleviate mechanical hyperalgesia in mice and increase the mechanical withdrawal threshold to a level that was $80 \%$ of the normal group [73]. These findings demonstrated that saikosaponins exert an antinociceptive effect on chemotherapy-induced peripheral neuropathy by targeting TRPA1. 


\subsection{Glycosides and Membrane Receptors}

Glycosides are orthosteric agonists of the G-protein-coupled receptor (GPCR) and act by the extracellular $\mathrm{N}$-terminal ectodomain interacting with the $\mathrm{C}$-terminal residues of cognate ligands, which positions the $\mathrm{N}$-terminus of the ligand to interact with critical determinants in the receptor's transmembrane region, thus leading to full activation and signal transduction. Previous studies have shown that a variety of GPCRs are involved in the antinociceptive process for neuropathic pain, including G-protein-coupled receptor 160 (GRP160) [130], G-protein-coupled receptor 34 (GPR34) [131], G-protein-coupled receptor 40 (GPR40) [132-134], and GLP-1R [77,135]. The class B G-protein-coupled GLP-1Rs are widely distributed in human islets, lungs, the cardiovascular system, the central nervous system, and other tissues. The main signal transduction pathways are calcium and the cAMP/PKA signal pathway $[136,137]$. Glycosides featuring a scaffold of cyclopentapyran with a double bond between $\mathrm{C} 7$ and $\mathrm{C} 8$ are reversible and orthosteric agonists of GLP$1 R$. The binding of GLP-1R to its ligand (GLP-1) leads to the pancreatic $\beta$ cells releasing glucose-dependent insulin; therefore, GLP-1R is a key target for the treatment of type 2 diabetes $[135,138-141]$. Subsequently, researchers discovered that GLP-1R is a potential therapeutic target for a variety of chronic pain conditions and not just diabetes. The activation of GLP-1R, which is specifically expressed in the microglia of the spinal dorsal horn, subsequently results in the activation of the cAMP/PKA/p38 $\beta /$ CREB signaling pathway. Autocrine IL-10 then regulates the release of $\beta$-Endorphin from the microglia; $\beta$-Endorphin then mediates diverse inhibitory effects in hypersensitive pain states by acting on $\mu$-receptors, rather than the antinociceptive effect produced by the anti-inflammatory activity of anti-inflammatory cytokines [135,142].

Morroniside is the major glycoside active constituent of Cornus officinalis (C. officinalis) Sieb. Et Zucc. and features a scaffold of cyclopentapyran with a double bond between C7 and C8. Studies have confirmed that the antinociceptive effect of morroniside on neuropathic pain is produced via the GLP-1R receptor. Morroniside is a reversible and orthosteric agonist of GLP-1R [143]. Exendin (9-39) is a specific antagonist of GLP-1Rs. In a previous

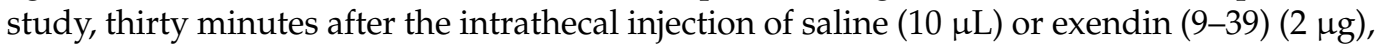
a rat model of neuropathic pain was orally administrated with morroniside $(300 \mathrm{mg} / \mathrm{kg})$ or given an intrathecal injection of morroniside $(100 \mu \mathrm{g})$. These researchers clearly observed mechanical anti-allodynia in the ipsilateral paws in the saline group. Conversely, the mechanical anti-allodynia effect of morroniside in the lesion was completely blocked by exendin (9-39), a GLP-1R antagonist [76]. Furthermore, Tang et al. studied the downstream mechanisms underlying the antinociceptive effect of morroniside on neuropathic pain via the activation of GLP-1R. Using a mouse model of neuropathic pain, researchers applied minocycline (a microglial inhibitor) or clodronate liposom (a microglial depletory agent) for $4 \mathrm{~h}$ or one day prior to morroniside treatment. This treatment reversed the antinociceptive effect of morroniside. However, the antinociceptive effect of morroniside can be reversed, thus indicating that the antinociceptive effect of morroniside occurs in microglia. Subsequently, the application of the IL-10 antibody, a $\beta$-Endorphin antibody, and a $\mu$-Opioid receptor antagonist (CTAP) also showed that the antinociceptive effect of morroniside was reversed. Furthermore, molecular biological techniques showed that morroniside promotes the release of IL-10 mRNA and $\beta$-Endorphin precursor proopiomelanocortin (POMC) mRNA in vivo and in vitro, thus verifying that morroniside produces therapeutic effects in neuropathy via the spinal microglial expression of IL-10 and the subsequent secretion of $\beta$-Endorphin after the activation of GLP-1R [77]. Likewise, geniposide is one of the main active components of the medicinal plant Gardenia jasminoides Ellis. Geniposide also features a scaffold of cyclopentapyran, with a double bond between C7 and C8; this produces antinociception during persistent pain by activating the spinal GLP-1Rs. Furthermore, the iridoids represented by geniposide are known to be orthosteric agonists of GLP-1Rs and exert similar functionality in humans and rats and presumably act at the same binding site as exendin (9-39) [107] (Figure 2). 


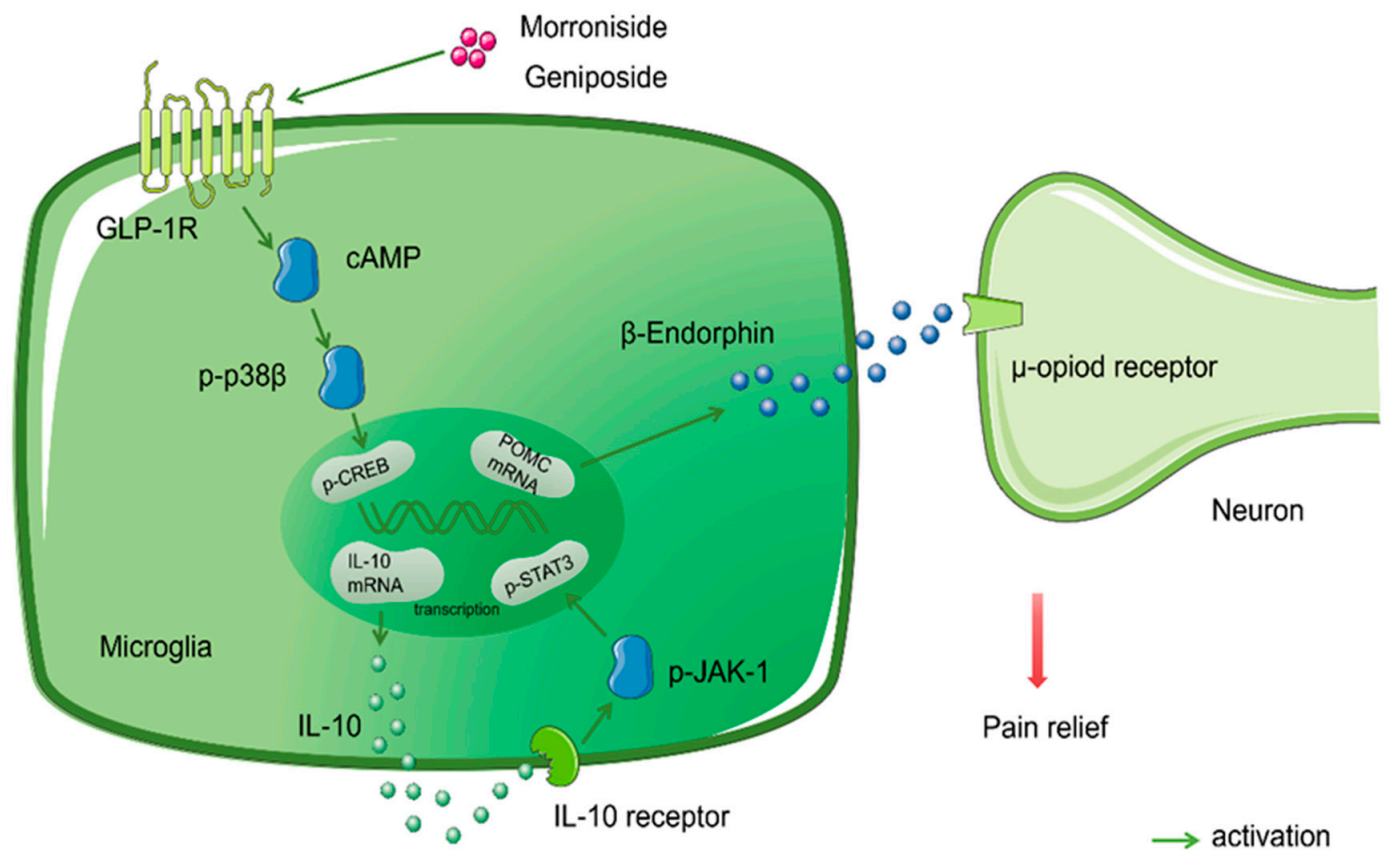

Figure 2. Glycosides and membrane receptors. Morroniside and geniposide activated GLP-1R (one of GPCRs), via IL-10/ $\beta$-Endorphin signaling pathways mediated analgesia in neuropathic pain.

\section{Conclusions and Future Perspectives}

In this review, a summary of the existing commonly used drugs helps to choose the appropriate treatment [37]. Understanding the mechanism of action of drugs is helpful to obtain optimal analgesics. The antinociceptive effect and mechanism of glycosides derived from medicinal plants are described, which facilitates mechanism-based identification of potential drug targets, and provides insights and ideas for the development of new drugs, playing an important role in the treatment of neuropathic pain.

Glycosides exert extensive biological activities and pharmacological effects. Aside from their antinociceptive effect on neuropathic pain, glycosides can also be used to treat a variety of diseases. Glycosides can be used to inhibit cancer [144], manage heart ailments [145], and alleviate atherosclerosis [146].

Although there are many glycosides, there is insufficient research relating to their antinociceptive effect for neuropathic pain. There are several reasons for this. First, poor oral bioavailability; in native forms the glycosides are not absorbed and have to be hydrolyzed by intestinal enzymes or by colonic microflora before absorption [56]. Second, glycosides are unstable, they are easily hydrolyzed into glycosyl and aglycone by acid, alkali and enzyme, so the prototype and metabolite which plays an antinociceptive role is in doubt [147]. Third, water solubility, poor fat solubility and weak membrane permeability limit glycoside penetration into the central nervous system. Fourth, the safety of glycosides is not completely clear.

Studies have shown that protein-ligand complexes can be used to maintain the stability of bioactive components. At $\mathrm{pH} 6.3$, a whey protein isolate was thermally modified at $85^{\circ} \mathrm{C}$ to act as a carrier for compound cyanidin-3-o-glucoside (C3G) and was subsequently combined with small molecular antioxidants. The $\mathrm{C} 3 \mathrm{G}$ residue within the protein-ligand complex reached a total of $36.8 \%$ after 30 days storage at $25^{\circ} \mathrm{C}$ [148]. Currently, the most commonly used strategy to alter membrane permeability is the hydroxyl acylation of glycosides or the preparation of esters. For example, researchers have studied the acylation of salidroside and found that synthesized salidroside acrylate derivatives exhibit a certain neuroprotective effect [149]. Chemical modifications can increase their potency. Collectively, these data suggest that glycoside analgesia is a promising strategy for the future [99]. 
In this review, we describe multiple mechanisms, such as oxidative stress, proinflammation, ion channels, and membrane receptors; these mechanisms are all associated with neuropathic pain. Mitochondria are the main intracellular source of production for ATP, ROS, and reactive nitrogen species (RNS). The mitochondria are also involved in many other cellular functions including $\mathrm{Ca}^{2+}$ signaling and apoptosis [150]. Multiple TRP channel subtypes (such as TRPM2, TRPM4, TRPM3, TRPC3, TRPC4, TRPV1, TRPV4, and TRPA1) are targeted by oxidative stress and a variety of by-products. TRPA1 is the main sensor of oxidative stress and nitrative stress associated with pain [151-153]. The sensitization of TRPA1 by $\mathrm{Ca}^{2+}$, ROS, RNS, and their by-products reactive carbonyl species (RCS) could lead to a prolonged period of hypersensitivity to mechanical and cold stimuli. On the other hand, TRPA1 produces and releases neuropeptide substance $\mathrm{P}$ (SP) and calcitonin generelated peptide (CGRP), thus resulting in neurogenic inflammation $[108,154]$. ROS activates NLRP3 and ASC in the NLRP3 inflammasome to increase the release of IL-1 $\beta$. This process promotes neuropathic pain and activates MMP-9, thus causing glial cells to activate and release many pro-inflammation factors, thus resulting in neuro-inflammation [75,80]. ATP produced by the mitochondria activates $\mathrm{P} 2 \mathrm{X}$ and $\mathrm{P} 2 \mathrm{Y}$ purinergic receptors. $\mathrm{P} 2 \mathrm{X}$ receptors are trimeric ATP-gated cation channels that are permeable to sodium, potassium, and calcium. These channels can open within milliseconds of ATP-binding $[155,156]$. Using extracellular ATP as a pro-inflammatory molecule, P2X receptors can trigger inflammation in response to high ATP release, thus causing neuropathic pain [157]. However, with respect to the functional ability of glycosides, there are only a few TRP channel subtypes. P2 purinergic receptors have been investigated due to their association with neuropathic pain (e.g., TRPA1 and the P2X7 receptor). It is important that we investigate interactions between multiple mechanisms in more detail in the future.

The main purpose of drug research is for the drug to go to market. For glycosides, the following steps are generally adopted: the establishment of a biological hypothesis of the mechanisms involved in the pathology of pain; the identification of a potential molecular target based on the biologic hypothesis to screen for new analgesic glycosides with higher potency and better safety; the optimization of its structure and the testing in animal models; and the preparation for a three-phase clinical trial. If all the above steps are carried out smoothly, then the glycosides which were selected can be used clinically.

Author Contributions: Conceptualization and Funding Acquisition, N.L., X.-B.L. and Y.-X.L.; Project Administration and Supervision, P.Z. and J.-Q.Y.; Original Draft Preparation and Methodology, M.-M.T. and S.L.; Data Collection, C.-H.Z., J.D., L.M. and J.-M.Y. All authors have read and agreed to the published version of the manuscript.

Funding: This study was supported by grants from the National Natural Science Foundation of China (81960726) and the Natural Science Foundation of Ningxia (2019AAC03097, 2021AAC03139).

Conflicts of Interest: The authors declare no conflict of interest.

\section{Abbreviations}

$\begin{array}{ll}\text { IASP } & \text { International Association for the Study of Pain } \\ \text { CNS } & \text { Central nervous system } \\ \text { PNS } & \text { Peripheral nervous system } \\ \text { HIV } & \text { Human immunodeficiency virus } \\ \text { COVID-19 } & \text { Coronavirus disease 2019 } \\ \text { SARS-CoV-2 } & \text { Severe acute respiratory syndrome coronavirus 2 } \\ \text { GRADE } & \text { Grading of Recommendations Assessment, Development, and Evaluation } \\ \text { NeuPSIG } & \text { Special Interest Group on Neuropathic Pain } \\ \text { LNP } & \text { Localized neuropathic pain } \\ \text { PWT } & \text { Paw withdrawal threshold } \\ \text { PWL } & \text { Paw withdrawal latencies } \\ \text { CCI } & \text { Chronic constriction injury } \\ \text { SNL } & \text { Spinal nerve ligation }\end{array}$




\begin{tabular}{|c|c|}
\hline TWL & Tail withdrawal latencies \\
\hline STZ & streptozotocin \\
\hline H\&E staining & Hematoxylin-eosin staining \\
\hline $\mathrm{C}_{\max }$ & Mean peak concentration \\
\hline $\mathrm{T}_{\max }$ & Mean peak time \\
\hline $\mathrm{T}_{1 / 2}$ & Half-life \\
\hline NLRP3 & NOD-like receptor protein 3 \\
\hline MCC950 & A selective inhibitor of the NLRP3 inflammasome \\
\hline ZDF & Zucker diabetic fatty \\
\hline T2DM & Type 2 diabetes mellitus \\
\hline HPLC-MS & High Performance Liquid Chromatography-Mass Spectrometry \\
\hline ROS & Reactive oxygen species \\
\hline MIA & Monoiodoacetate \\
\hline AUC & Area under curve \\
\hline PTX & Paclitaxel \\
\hline TNF- $\alpha$ & Tumor Necrosis Factor-Alpha \\
\hline IL-1 $\beta$ & Interleukin-1 $\beta$ \\
\hline IL-6 & Interleukin-6 \\
\hline IL-10 & Interleukin-10 \\
\hline UHPLC-MS & $\begin{array}{l}\text { ultra-high-performance liquid chromatography tandem } \\
\text { mass spectrometry }\end{array}$ \\
\hline MMPs & Matrix metalloproteinases \\
\hline T-AOC & Total antioxidant capacity \\
\hline CAT & Catalase \\
\hline T-SOD & Total superoxide dismutase \\
\hline MAD & Malondialdehyde \\
\hline NF- $\kappa B$ & Nuclear factor kappa B \\
\hline Keap1 & Kelch-like ECH associated protein 1 \\
\hline Nrf2 & Nuclear factor erythroid 2-related factor 2 \\
\hline ATP & Adenosine triphosphate \\
\hline P2X7R & $\mathrm{P} 2 \mathrm{X}$ receptor 7 \\
\hline TRPA1 & Transient receptor potential ankyrin 1 \\
\hline TRP & Transient receptor potential \\
\hline HPS & High-throughput screening \\
\hline GPCR & G-protein-coupled receptor \\
\hline GRP160 & G-protein-coupled receptor 160 \\
\hline GPR34 & G-protein-coupled receptor 34 \\
\hline GPR40 & G-protein-coupled receptor 40 \\
\hline GLP-1R & Glucagon-like peptide-1 receptor \\
\hline CTAP & $\mu$-Opioid receptor antagonist \\
\hline POMC & $\beta$-Endorphin precursor proopiomelanocortin \\
\hline C3G & Cyanidin-3-o-glucoside \\
\hline RNS & Reactive nitrogen species \\
\hline TRPM2 & Transient receptor potential melastatin 2 \\
\hline TRPM3 & Transient receptor potential melastatin 3 \\
\hline TRPM4 & Transient receptor potential melastatin 4 \\
\hline TRPC3 & Transient receptor potential channel canonical 3 \\
\hline TRPC4 & Transient receptor potential channel canonical 4 \\
\hline TRPV1 & Transient receptor potential vanilloid type 1 \\
\hline TRPV4 & Transient receptor potential vanilloid type 4 \\
\hline RCS & Reactive carbonyl species \\
\hline SP & Substance P \\
\hline CGRP & Calcitonin gene-related peptide \\
\hline
\end{tabular}




\section{References}

1. Treede, R.D.; Jensen, T.S.; Campbell, J.N.; Cruccu, G.; Dostrovsky, J.O.; Griffin, J.W.; Hansson, P.; Hughes, R.; Nurmikko, T.; Serra, J. Neuropathic pain: Redefinition and a grading system for clinical and research purposes. Neurology 2007, 70, 1630-1635. [CrossRef]

2. Boyd, A.; Bleakley, C.; Hurley, D.A.; Gill, C.; Hannon-Fletcher, M.; Bell, P.; McDonough, S. Herbal medicinal products or preparations for neuropathic pain. Cochrane Database Syst. Rev. 2019, 4, CD010528. [CrossRef] [PubMed]

3. Finnerup, N.; Kuner, R.; Jensen, T. Neuropathic Pain: From Mechanisms to Treatment. Physiol. Rev. 2021, 101, 259-301. [CrossRef]

4. YB, T. Effect of Bone Mesenchymal Stromal Cells on Neuropathic Pain and Its Mechanism; Shandong University: Jinan, China, 2020.

5. Haanpää, M.; Backonja, M.; Bennett, M.; Bouhassira, D.; Cruccu, G.; Hansson, P.; Jensen, T.; Kauppila, T.; Rice, A.; Smith, B.; et al. Assessment of neuropathic pain in primary care. Am. J. Med. 2009, 122, S13-S21. [CrossRef] [PubMed]

6. Truini, A.; Garcia-Larrea, L.; Cruccu, G. Reappraising neuropathic pain in humans-how symptoms help disclose mechanisms. Nat. Rev. Neurol. 2013, 9, 572-582. [CrossRef]

7. Calvo, M.; Dawes, J.M.; Bennett, D.L.H. The role of the immune system in the generation of neuropathic pain. Lancet Neurol. 2012, 11, 629-642. [CrossRef]

8. Torrance, N.; Lawson, K.D.; Afolabi, E.; Bennett, M.I.; Serpell, M.G.; Dunn, K.M.; Smith, B.H. Estimating the burden of disease in chronic pain with and without neuropathic characteristics: Does the choice between the EQ-5D and SF-6D matter? Pain 2014, 155, 1996-2004. [CrossRef]

9. Colloca, L.; Ludman, T.; Bouhassira, D.; Baron, R.; Dickenson, A.; Yarnitsky, D.; Freeman, R.; Truini, A.; Attal, N.; Finnerup, N.; et al. Neuropathic pain. Nat. Rev. Dis. Primers 2017, 3, 17002. [CrossRef]

10. Attal, N.; Lanteri-Minet, M.; Laurent, B.; Fermanian, J.; Bouhassira, D. The specific disease burden of neuropathic pain: Results of a French nationwide survey. Pain 2011, 152, 2836-2843. [CrossRef]

11. Wiffen, P.; Collins, S.; McQuay, H.; Carroll, D.; Jadad, A.; Moore, A. Anticonvulsant drugs for acute and chronic pain. Cochrane Database Syst. Rev. 2005, 2000, CD001133. [CrossRef]

12. Metcalfe, A.; Williams, J.; McChesney, J.; Patten, S.; Jetté, N. Use of complementary and alternative medicine by those with a chronic disease and the general population-Results of a national population based survey. BMC Complement. Altern. Med. 2010, 10, 58. [CrossRef] [PubMed]

13. Ngo, L.T.; Okogun, J.I.; Folk, W.R. 21st century natural product research and drug development and traditional medicines. Nat. Prod. Rep. 2013, 30, 584-592. [CrossRef] [PubMed]

14. Basu, P.; Basu, A. In Vitro and In Vivo Effects of Flavonoids on Peripheral Neuropathic Pain. Molecules 2020, 25, 1171. [CrossRef] [PubMed]

15. Santos, J.; Santos, C.; Freitas Filho, J.; Menezes, P.; Freitas, J. Polyacetylene Glycosides: Isolation, Biological Activities and Synthesis. Chem. Rec. 2021. [CrossRef]

16. Tian, X.; Li, M.; Lin, T.; Qiu, Y.; Zhu, Y.; Li, X.; Tao, W.; Wang, P.; Ren, X.; Chen, L. A review on the structure and pharmacological activity of phenylethanoid glycosides. Eur. J. Med. Chem. 2021, 209, 112563. [CrossRef]

17. Khan, H.; Pervaiz, A.; Intagliata, S.; Das, N.; Nagulapalli Venkata, K.C.; Atanasov, A.G.; Najda, A.; Nabavi, S.M.; Wang, D.; Pittalà, V.; et al. The analgesic potential of glycosides derived from medicinal plants. DARU J. Pharm. Sci. 2020, 28, 387-401. [CrossRef]

18. Sa, K.N.; Moreira, L.; Baptista, A.F.; Yeng, L.T.; Teixeira, M.J.; Galhardoni, R.; de Andrade, D.C. Prevalence of chronic pain in developing countries: Systematic review and meta-analysis. Pain Rep. 2019, 4, e779. [CrossRef]

19. King, S.; Chambers, C.; Huguet, A.; MacNevin, R.; McGrath, P.; Parker, L.; MacDonald, A. The epidemiology of chronic pain in children and adolescents revisited: A systematic review. Pain 2011, 152, 2729-2738. [CrossRef]

20. Hechler, T.; Dobe, M.; Zernikow, B. Commentary: A worldwide call for multimodal inpatient treatment for children and adolescents suffering from chronic pain and pain-related disability. J. Pediatr. Psychol. 2010, 35, 138-140. [CrossRef]

21. Huguet, A.; Miró, J. The severity of chronic pediatric pain: An epidemiological study. J. Pain 2008, 9, 226-236. [CrossRef]

22. De Toledo, I.; Conti Réus, J.; Fernandes, M.; Porporatti, A.; Peres, M.; Takaschima, A.; Linhares, M.; Guerra, E.; De Luca Canto, G. Prevalence of trigeminal neuralgia: A systematic review. J. Am. Dent. Assoc. 2016, 147, 570-576.e572. [CrossRef]

23. van Hecke, O.; Austin, S.K.; Khan, R.A.; Smith, B.H.; Torrance, N. Neuropathic pain in the general population: A systematic review of epidemiological studies. Pain 2014, 155, 654-662. [CrossRef]

24. van Hecke, O.; Torrance, N.; Smith, B. Chronic pain epidemiology and its clinical relevance. Br. J. Anaesth. 2013, 111, 13-18. [CrossRef] [PubMed]

25. Ohayon, M.M.; Stingl, J.C. Prevalence and comorbidity of chronic pain in the German general population. J. Psychiatr. Res. 2012, 46, 444-450. [CrossRef] [PubMed]

26. Torrance, N.; Smith, B.; Bennett, M.; Lee, A. The epidemiology of chronic pain of predominantly neuropathic origin. Results from a general population survey. J. Pain 2006, 7, 281-289. [CrossRef]

27. Bouhassira, D.; Lantéri-Minet, M.; Attal, N.; Laurent, B.; Touboul, C. Prevalence of chronic pain with neuropathic characteristics in the general population. Pain 2008, 136, 380-387. [CrossRef]

28. VanDenKerkhof, E.G.; Mann, E.G.; Torrance, N.; Smith, B.H.; Johnson, A.; Gilron, I. An Epidemiological Study of Neuropathic Pain Symptoms in Canadian Adults. Pain Res. Manag. 2016, 2016, 9815750. [CrossRef]

29. Feldman, E.L.; Callaghan, B.C.; Pop-Busui, R.; Zochodne, D.W.; Wright, D.E.; Bennett, D.L.; Bril, V.; Russell, J.W.; Viswanathan, V. Diabetic neuropathy. Nat. Rev. Dis Primers 2019, 5, 41. [CrossRef] [PubMed] 
30. Ciaramitaro, P.; Padua, L.; Devigili, G.; Rota, E.; Tamburin, S.; Eleopra, R.; Cruccu, G.; Truini, A. Prevalence of Neuropathic Pain in Patients with Traumatic Brachial Plexus Injury: A Multicenter Prospective Hospital-Based Study. Pain Med. 2017, 18, $2428-2432$. [CrossRef]

31. Lechner, B.; Chow, S.; Chow, R.; Zhang, L.; Tsao, M.; Danjoux, C.; Barnes, E.; DeAngelis, C.; Vuong, S.; Ganesh, V.; et al. The incidence of neuropathic pain in bone metastases patients referred for palliative radiotherapy. Radiother. Oncol. 2016, 118, 557-561. [CrossRef]

32. Orhurhu, M.S.; Chu, R.; Claus, L.; Roberts, J.; Salisu, B.; Urits, I.; Orhurhu, E.; Viswanath, O.; Kaye, A.D.; Kaye, A.J.; et al. Neuropathic Pain and Sickle Cell Disease: A Review of Pharmacologic Management. Curr. Pain Headache Rep. 2020, $24,52$. [CrossRef]

33. Yanaizumi, R.; Nagamine, Y.; Harada, S.; Kojima, K.; Tazawa, T.; Goto, T. Prevalence of neuropathic pain in terminally ill patients with cancer admitted to a general ward: A prospective observational study. J. Int. Med. Res. 2021, 49, 0300060520987726. [CrossRef] [PubMed]

34. Clauw, D.; Häuser, W.; Cohen, S.; Fitzcharles, M. Considering the potential for an increase in chronic pain after the COVID-19 pandemic. Pain 2020, 161, 1694-1697. [CrossRef]

35. Mao, L.; Jin, H.; Wang, M.; Hu, Y.; Chen, S.; He, Q.; Chang, J.; Hong, C.; Zhou, Y.; Wang, D.; et al. Neurologic Manifestations of Hospitalized Patients with Coronavirus Disease 2019 in Wuhan, China. JAMA Neurol. 2020, 77, 683-690. [CrossRef]

36. Attal, N.; Martinez, V.; Bouhassira, D. Potential for increased prevalence of neuropathic pain after the COVID-19 pandemic. Pain Rep. 2021, 6, e884. [CrossRef]

37. Yan, Y.Y.; Li, C.Y.; Zhou, L.; Ao, L.Y.; Fang, W.R.; Li, Y.M. Research progress of mechanisms and drug therapy for neuropathic pain. Life Sci. 2017, 190, 68-77. [CrossRef]

38. Finnerup, N.B.; Attal, N.; Haroutounian, S.; McNicol, E.; Baron, R.; Dworkin, R.H.; Gilron, I.; Haanpää, M.; Hansson, P.; Jensen T.S.; et al. Pharmacotherapy for neuropathic pain in adults: A systematic review and meta-analysis. Lancet Neurol. 2015, 14, 162-173. [CrossRef]

39. Boyle, J.; Eriksson, M.E.; Gribble, L.; Gouni, R.; Johnsen, S.; Coppini, D.V.; Kerr, D. Randomized, placebo-controlled comparison of amitriptyline, duloxetine, and pregabalin in patients with chronic diabetic peripheral neuropathic pain: Impact on pain, polysomnographic sleep, daytime functioning, and quality of life. Diabetes Care 2012, 35, 2451-2458. [CrossRef] [PubMed]

40. Pickering, G.; Voute, M.; Macian, N.; Ganry, H.; Pereira, B. Effectiveness and safety of 5\% lidocaine-medicated plaster on localized neuropathic pain after knee surgery: A randomized, double-blind controlled trial. Pain 2019, 160, 1186-1195. [CrossRef] [PubMed]

41. Robertson, K.; Marshman, L.A.G.; Plummer, D.; Downs, E. Effect of Gabapentin vs Pregabalin on Pain Intensity in Adults with Chronic Sciatica: A Randomized Clinical Trial. JAMA Neurol. 2019, 76, 28-34. [CrossRef] [PubMed]

42. Nalamachu, S.; Morley-Forster, P. Diagnosing and managing postherpetic neuralgia. Drugs Aging 2012, 29, 863-869. [CrossRef]

43. Henningfield, J.E.; Ashworth, J.B.; Gerlach, K.K.; Simone, B.; Schnoll, S.H. The nexus of opioids, pain, and addiction: Challenges and solutions. Prev. Med. 2019, 128, 105852. [CrossRef]

44. Doostmohammadi, M.; Rahimi, H.R. ADME and toxicity considerations for tramadol: From basic research to clinical implications. Expert Opin. Drug Metab. Toxicol. 2020, 16, 627-640. [CrossRef] [PubMed]

45. Xinyaohui. Available online: http://www.xinyaohui.com/news/201510/29/7237.html (accessed on 1 December 2021).

46. Lu, Y.; Hou, S.; Chen, T. Advances in the study of vincristine: An anticancer ingredient from Catharanthus roseus. Zhongguo Zhong Yao Za Zhi = Zhongguo Zhongyao Zazhi = China J. Chin. Mater. Med. 2003, 28, 1006-1009.

47. Wu, X.; Xie, H.; Long, X.; Zhang, J.; Huang, T.; Hao, X.; Zhang, Y. Chemical constituents of Catharanthus roseus. J. Chin. Pharm. Sci. 2017, 52, 631-636

48. Yuan, Y.; Jiang, T.; Zhou, X.; Liu, Y. Discovery and development of artemisinin. Chin. Sci. Bull. 2017, 62, 1914-1927. [CrossRef]

49. Li, S.-H.; Li, L.; Yang, R.-N.; Liang, S.-D. Compounds of traditional Chinese medicine and neuropathic pain. Chin. J. Nat. Med. 2020, 18, 28-35. [CrossRef]

50. Cheeke, P.R. Glycosides: Naturally Occurring; ENCYCLOPEDIA OF LIFE SCIENCE; John Wiley \& Sons, Ltd: Hoboken, NJ, USA, 2001.

51. Yu, B.; Sun, J.; Yang, X. Assembly of naturally occurring glycosides, evolved tactics, and glycosylation methods. Acc. Chem. Res. 2012, 45, 1227-1236. [CrossRef]

52. Weymouth-Wilson, A.C. The role of carbohydrates in biologically active natural products. Nat. Prod. Rep. 1997, 14, 99-110. [CrossRef] [PubMed]

53. Jia, X.H.; Wang, C.Q.; Liu, J.H.; Li, X.W.; Wang, X.; Shang, M.Y.; Cai, S.Q.; Zhu, S.; Komatsu, K. Comparative studies of saponins in 1-3-year-old main roots, fibrous roots, and rhizomes of Panax notoginseng, and identification of different parts and growth-year samples. J. Nat. Med. 2013, 67, 339-349. [CrossRef] [PubMed]

54. Zhu, Q.; Mao, L.-N.; Liu, C.-P.; Sun, Y.-H.; Jiang, B.; Zhang, W.; Li, J.-X. Antinociceptive effects of vitexin in a mouse model of postoperative pain. Sci. Rep. 2016, 6, 19266. [CrossRef]

55. Zhou, X.; Cheng, H.; Xu, D.; Yin, Q.; Cheng, L.; Wang, L.; Song, S.; Zhang, M. Attenuation of neuropathic pain by saikosaponin a in a rat model of chronic constriction injury. Neurochem. Res. 2014, 39, 2136-2142. [CrossRef]

56. Ribeiro, M.H.L. Glycosides. In Biotechnology of Bioactive Compounds; Wiley-Blackwell: Hoboken, NJ, USA, 2015; pp. 301-344. [CrossRef] 
57. Zuo, A.; Dong, H.; Yu, Y.; Shu, Q.; Zheng, L.; Yu, X.; Cao, S. The antityrosinase and antioxidant activities of flavonoids dominated by the number and location of phenolic hydroxyl groups. Chin. Med. 2018, 13, 51. [CrossRef]

58. Zhou, J.; Wang, J.; Li, W.; Wang, C.; Wu, L.; Zhang, J. Paeoniflorin attenuates the neuroinflammatory response in a rat model of chronic constriction injury. Mol. Med. Rep. 2017, 15, 3179-3185. [CrossRef] [PubMed]

59. Li, Y.; Qiao, J.; Wang, B.; Bai, M.; Shen, J.; Cheng, Y. Paeoniflorin Ameliorates Fructose-Induced Insulin Resistance and Hepatic Steatosis by Activating LKB1/AMPK and AKT Pathways. Nutrients 2018, 10, 1024. [CrossRef]

60. Zhu, L.; Liu, Z.; Ren, Y.; Wu, X.; Liu, Y.; Wang, T.; Li, Y.; Cong, Y.; Guo, Y. Neuroprotective effects of salidroside on ageing hippocampal neurons and naturally ageing mice via the PI3K/Akt/TERT pathway. Phytother. Res. PTR 2021, 35, 5767-5780. [CrossRef] [PubMed]

61. Ni, G.L.; Cui, R.; Shao, A.M.; Wu, Z.M. Salidroside Ameliorates Diabetic Neuropathic Pain in Rats by Inhibiting Neuroinflammation. J. Mol. Neurosci. 2017, 63, 9-16. [CrossRef] [PubMed]

62. Baron, R.; Binder, A.; Wasner, G. Neuropathic pain: Diagnosis, pathophysiological mechanisms, and treatment. Lancet. Neurol. 2010, 9, 807-819. [CrossRef]

63. Sonza, A.; Sanada, L.; Oliveira, L.; Bernardo-Filho, M.; Sá-Caputo, D.; Zaro, M.; Achaval, M. Whole-body vibration mediates mechanical hypersensitivity through $\mathrm{A} \beta$-fiber and $\mathrm{C}$-fiber thermal sensation in a chronic pain model. Exp. Biol. Med. (Maywood N. J.) 2021, 246, 1210-1218. [CrossRef] [PubMed]

64. Jensen, T.S.; Finnerup, N.B. Allodynia and hyperalgesia in neuropathic pain: Clinical manifestations and mechanisms. Lancet Neurol. 2014, 13, 924-935. [CrossRef]

65. Zheng, R.; Fu, Y.; Zhu, J.; Xu, J.; Xiang, Q.; Chen, L.; Zhong, H.; Li, J.; Yu, C. Long-term low-dose morphine for patients with moderate cancer pain is predominant factor effecting clinically meaningful pain reduction. Supportive Care Cancer Off. J. Multinatl. Assoc. Supportive Care Cancer 2018, 26, 4115-4120. [CrossRef] [PubMed]

66. Sandkühler, J. Models and mechanisms of hyperalgesia and allodynia. Physiol. Rev. 2009, 89, 707-758. [CrossRef]

67. Nipornram, S.; Tochampa, W.; Rattanatraiwong, P.; Singanusong, R. Optimization of low power ultrasound-assisted extraction of phenolic compounds from mandarin (Citrus reticulata Blanco cv. Sainampueng) peel. Food Chem. 2018, 241, 338-345. [CrossRef] [PubMed]

68. Tao, J.; Liu, L.; Fan, Y.; Wang, M.; Li, L.; Zou, L.; Yuan, H.; Shi, L.; Yang, R.; Liang, S.; et al. Role of hesperidin in P2X3 receptor-mediated neuropathic pain in the dorsal root ganglia. Int. J. Neurosci. 2019, 129, 784-793. [CrossRef]

69. Carballo-Villalobos, A.I.; Gonzalez-Trujano, M.E.; Alvarado-Vazquez, N.; Lopez-Munoz, F.J. Pro-inflammatory cytokines involvement in the hesperidin antihyperalgesic effects at peripheral and central levels in a neuropathic pain model. Inflammopharmacology 2017, 25, 265-269. [CrossRef] [PubMed]

70. Visnagri, A.; Kandhare, A.D.; Chakravarty, S.; Ghosh, P.; Bodhankar, S.L. Hesperidin, a flavanoglycone attenuates experimental diabetic neuropathy via modulation of cellular and biochemical marker to improve nerve functions. Pharm. Biol. 2014, 52, 814-828. [CrossRef] [PubMed]

71. Sun, T.; Luo, J.; Xu, Y.; Sun, X.; Yang, S.; Yang, M. Ultra-high performance supercritical fluid chromatography method for separation and quantitation of saikosaponins in herbal medicine. J. Pharm. Biomed. Anal. 2021, 199, 114039. [CrossRef] [PubMed]

72. Carballo-Villalobos, A.I.; Gonzalez-Trujano, M.E.; Pellicer, F.; Alvarado-Vasquez, N.; Lopez-Munoz, F.J. Central and peripheral anti-hyperalgesic effects of diosmin in a neuropathic pain model in rats. Biomed. Pharmacother. 2018, 97, 310-320. [CrossRef] [PubMed]

73. Bertozzi, M.M.; Rossaneis, A.C.; Fattori, V.; Longhi-Balbinot, D.T.; Freitas, A.; Cunha, F.Q.; Alves-Filho, J.C.; Cunha, T.M.; Casagrande, R.; Verri, W.A., Jr. Diosmin reduces chronic constriction injury-induced neuropathic pain in mice. Chem. Biol. Interact 2017, 273, 180-189. [CrossRef] [PubMed]

74. Amin, B.; Poureshagh, E.; Hosseinzadeh, H. The Effect of Verbascoside in Neuropathic Pain Induced by Chronic Constriction Injury in Rats. Phytother. Res. 2016, 30, 128-135. [CrossRef]

75. Lee, G.; Choi, J.; Nam, Y.J.; Song, M.J.; Kim, J.K.; Kim, W.J.; Kim, P.; Lee, J.S.; Kim, S.; No, K.T.; et al. Identification and characterization of saikosaponins as antagonists of transient receptor potential A1 channel. Phytother. Res. 2020, 34, 788-795. [CrossRef]

76. Andoh, T.; Kobayashi, N.; Uta, D.; Kuraishi, Y. Prophylactic topical paeoniflorin prevents mechanical allodynia caused by paclitaxel in mice through adenosine A1 receptors. Phytomedicine 2017, 25, 1-7. [CrossRef]

77. Liu, P.; Cheng, J.; Ma, S.; Zhou, J. Paeoniflorin attenuates chronic constriction injury-induced neuropathic pain by suppressing spinal NLRP3 inflammasome activation. Inflammopharmacology 2020, 28, 1495-1508. [CrossRef] [PubMed]

78. Xu, M.; Wu, H.Y.; Liu, H.; Gong, N.; Wang, Y.R.; Wang, Y.X. Morroniside, a secoiridoid glycoside from Cornus officinalis, attenuates neuropathic pain by activation of spinal glucagon-like peptide-1 receptors. Br. J. Pharmacol. 2017, 174, 580-590. [CrossRef] [PubMed]

79. Tang, X.; Wu, H.; Mao, X.; Li, X.; Wang, Y. The GLP-1 receptor herbal agonist morroniside attenuates neuropathic pain via spinal microglial expression of IL-10 and beta-endorphin. Biochem. Biophys. Res. Commun. 2020, 530, 494-499. [CrossRef]

80. Zhang, M.T.; Wang, B.; Jia, Y.N.; Liu, N.; Ma, P.S.; Gong, S.S.; Niu, Y.; Sun, T.; Li, Y.X.; Yu, J.Q. Neuroprotective effect of liquiritin against neuropathic pain induced by chronic constriction injury of the sciatic nerve in mice. Biomed. Pharmacother. 2017, 95, 186-198. [CrossRef] [PubMed] 
81. Zheng, T.; Wang, Q.; Bian, F.; Zhao, Y.; Ma, W.; Zhang, Y.; Lu, W.; Lei, P.; Zhang, L.; Hao, X.; et al. Salidroside alleviates diabetic neuropathic pain through regulation of the AMPK-NLRP3 inflammasome axis. Toxicol. Appl. Pharmacol. 2021, 416, 115468. [CrossRef]

82. Zhang, G.; Liu, N.; Zhu, C.; Ma, L.; Yang, J.; Du, J.; Zhang, W.; Sun, T.; Niu, J.; Yu, J. Antinociceptive effect of isoorientin against neuropathic pain induced by the chronic constriction injury of the sciatic nerve in mice. Int. Immunopharmacol. 2019, $75,105753$. [CrossRef] [PubMed]

83. Liu, P.; Chen, J.; Ma, S.; Zhang, J.; Zhou, J. Albiflorin Attenuates Mood Disorders Under Neuropathic Pain State by Suppressing the Hippocampal NLRP3 Inflammasome Activation During Chronic Constriction Injury. Int. J. Neuropsychopharmacol. 2021, 24, 64-76. [CrossRef]

84. Wang, Y.; $\mathrm{Xu}, \mathrm{Z}$. Analgesic effect of geniposide on diabetic neuropathic pain in rats. Northwest Pharm. J. 2018, 33, $206-210$.

85. Anilkumar, K.; Reddy, G.V.; Azad, R.; Yarla, N.S.; Dharmapuri, G.; Srivastava, A.; Kamal, M.A.; Pallu, R. Evaluation of AntiInflammatory Properties of Isoorientin Isolated from Tubers of Pueraria tuberosa. Oxid. Med. Cell Longev. 2017, $2017,5498054$. [CrossRef]

86. Yuan, L.; Wang, J.; Xiao, H.; Wu, W.; Wang, Y.; Liu, X. MAPK signaling pathways regulate mitochondrial-mediated apoptosis induced by isoorientin in human hepatoblastoma cancer cells. Food Chem. Toxicol. 2013, 53, 62-68. [CrossRef]

87. Wu, Q.Y.; Wong, Z.C.; Wang, C.; Fung, A.H.; Wong, E.O.; Chan, G.K.; Dong, T.T.; Chen, Y.; Tsim, K.W. Isoorientin derived from Gentiana veitchiorum Hemsl. flowers inhibits melanogenesis by down-regulating MITF-induced tyrosinase expression. Phytomedicine 2019, 57, 129-136. [CrossRef]

88. Wang, H.; Shan, H.; Lu, H. Preparative Separation and Purification of Liquiritin and Glycyrrhizic Acid from Glycyrrhiza uralensis Fisch by High-Speed Countercurrent Chromatography. J. Chromatogr. Sci. 2020, 58, 823-830. [CrossRef]

89. Zhai, K.F.; Duan, H.; Cui, C.Y.; Cao, Y.Y.; Si, J.L.; Yang, H.J.; Wang, Y.C.; Cao, W.G.; Gao, G.Z.; Wei, Z.J. Liquiritin from Glycyrrhiza uralensis Attenuating Rheumatoid Arthritis via Reducing Inflammation, Suppressing Angiogenesis, and Inhibiting MAPK Signaling Pathway. J. Agric. Food Chem. 2019, 67, 2856-2864. [CrossRef]

90. Zhu, J.; Deng, Y.Q.; Wang, X.; Li, X.F.; Xie, Z. An artificial intelligence system reveals liquiritin inhibits SARS-CoV-2 by mimicking type I interferon. BioRxiv 2020. [CrossRef]

91. Wang, Y.; Wang, J.; Hu, X.; Chen, L.; Qiu, Z.; Zhao, N.; Yu, Z.; Sun, S.; Xu, Y.; Guo, Y.; et al. Antidepressant-like effects of albiflorin extracted from Radix paeoniae Alba. J. Ethnopharmacol. 2016, 179, 9-15. [CrossRef] [PubMed]

92. Zhao, Z.; Fu, J.; Ma, S.; Peng, R.; Yu, J.; Cong, L.; Pan, L.; Zhang, Z.; Tian, H.; Che, C.; et al. Gut-brain axis metabolic pathway regulates antidepressant efficacy of albiflorin. Theranostics 2018, 8, 5945-5959. [CrossRef] [PubMed]

93. Liu, S.; Zou, L.; Xie, J.; Xie, W.; Wen, S.; Xie, Q.; Gao, Y.; Li, G.; Zhang, C.; Xu, C.; et al. LncRNA NONRATT021972 siRNA regulates neuropathic pain behaviors in type 2 diabetic rats through the P2X7 receptor in dorsal root ganglia. Mol. Brain 2016, 9 , 44. [CrossRef]

94. Brussee, V.; Guo, G.; Dong, Y.; Cheng, C.; Martinez, J.A.; Smith, D.; Glazner, G.W.; Fernyhough, P.; Zochodne, D.W. Distal degenerative sensory neuropathy in a long-term type 2 diabetes rat model. Diabetes 2008, 57, 1664-1673. [CrossRef] [PubMed]

95. Kouitcheu Mabeku, L.B.; Noundjeu Ngamga, M.L.; Leundji, H. Helicobacter pylori infection, a risk factor for Type 2 diabetes mellitus: A hospital-based cross-sectional study among dyspeptic patients in Douala-Cameroon. Sci. Rep. 2020, 10, 12141. [CrossRef]

96. Yu, H.; Yao, S.; Zhou, C.; Fu, F.; Luo, H.; Du, W.; Jin, H.; Tong, P.; Chen, D.; Wu, C.; et al. Morroniside attenuates apoptosis and pyroptosis of chondrocytes and ameliorates osteoarthritic development by inhibiting NF- $\mathrm{kB}$ signaling. J. Ethnopharmacol. 2021, 266, 113447. [CrossRef]

97. Harris, C.S.; Asim, M.; Saleem, A.; Haddad, P.S.; Arnason, J.T.; Bennett, S.A. Characterizing the cytoprotective activity of Sarracenia purpurea L., a medicinal plant that inhibits glucotoxicity in PC12 cells. BMC Complement. Altern. Med. 2012, 12, 245. [CrossRef] [PubMed]

98. Xie, J.; Tan, F.; Zhu, J.; Yue, C.; Li, Q. Separation, purification and quantification of verbascoside from Penstemon barbatus (Cav.) Roth. Food Chem. 2012, 135, 2536-2541. [CrossRef] [PubMed]

99. Isacchi, B.; Iacopi, R.; Bergonzi, M.C.; Ghelardini, C.; Galeotti, N.; Norcini, M.; Vivoli, E.; Vincieri, F.F.; Bilia, A.R. Antihyperalgesic activity of verbascoside in two models of neuropathic pain. J. Pharm. Pharm. 2011, 63, 594-601. [CrossRef] [PubMed]

100. Lee, J.; Seo, K.; Ryu, H.; Yuk, H.; Park, H.; Lim, Y.; Ahn, K.; Oh, S. Anti-inflammatory effect of stem bark of Paulownia tomentosa Steud. in lipopolysaccharide (LPS)-stimulated RAW264.7 macrophages and LPS-induced murine model of acute lung injury. J. Ethnopharmacol. 2018, 210, 23-30. [CrossRef]

101. Di Giancamillo, A.; Rossi, R.; Vitari, F.; Carollo, V.; Deponti, D.; Corino, C.; Domeneghini, C. Changes in nitrosative stress biomarkers in swine intestine following dietary intervention with verbascoside. Histol. Histopathol. 2013, 28, 715-723. [CrossRef] [PubMed]

102. Wang, K.; Zhu, L.; Zhu, X.; Zhang, K.; Huang, B.; Zhang, J.; Zhang, Y.; Zhu, L.; Zhou, B.; Zhou, F. Protective effect of paeoniflorin on Abeta25-35-induced SH-SY5Y cell injury by preventing mitochondrial dysfunction. Cell Mol. Neurobiol. 2014, 34, 227-234. [CrossRef] [PubMed]

103. Cao, B.Y.; Yang, Y.P.; Luo, W.F.; Mao, C.J.; Han, R.; Sun, X.; Cheng, J.; Liu, C.F. Paeoniflorin, a potent natural compound, protects PC12 cells from MPP+ and acidic damage via autophagic pathway. J. Ethnopharmacol. 2010, 131, 122-129. [CrossRef] 
104. Hu, M.; Chen, C.; Liu, J.; Cai, L.; Shao, J.; Chen, Z.; Lin, L.; Zheng, T.; Ding, X.; Li, Z. The melanogenic effects and underlying mechanism of paeoniflorin in human melanocytes and vitiligo mice. Fitoterapia. 2020, 140, 104416. [CrossRef] [PubMed]

105. Srinivasan, S.; Vinothkumar, V.; Murali, R. Antidiabetic Efficacy of Citrus Fruits with Special Allusion to Flavone Glycosides. In Bioactive Food as Dietary Interventions for Diabetes; Academic Press: Cambridge, MA, USA, 2019; pp. 335-346. [CrossRef]

106. Wang, M.; Yang, L.; Chen, Z.; Dai, L.; Xi, C.; Wu, X.; Wu, G.; Wang, Y.; Hu, J. Geniposide ameliorates chronic unpredictable mild stress induced depression-like behavior through inhibition of ceramide-PP2A signaling via the PI3K/Akt/GSK3 $\beta$ axis. Psychopharmacology 2021, 238, 2789-2800. [CrossRef]

107. Gong, N.; Fan, H.; Ma, A.N.; Xiao, Q.; Wang, Y.X. Geniposide and its iridoid analogs exhibit antinociception by acting at the spinal GLP-1 receptors. Neuropharmacology 2014, 84, 31-45. [CrossRef] [PubMed]

108. Nassini, R.; Materazzi, S.; Benemei, S.; Geppetti, P. The TRPA1 channel in inflammatory and neuropathic pain and migraine. Rev. Physiol. Biochem. Pharm. 2014, 167,1-43. [CrossRef]

109. Lakhan, S.E.; Avramut, M. Matrix metalloproteinases in neuropathic pain and migraine: Friends, enemies, and therapeutic targets. Pain Res. Treat. 2012, 2012, 952906. [CrossRef] [PubMed]

110. Rojewska, E.; Makuch, W.; Przewlocka, B.; Mika, J. Minocycline prevents dynorphin-induced neurotoxicity during neuropathic pain in rats. Neuropharmacology 2014, 86, 301-310. [CrossRef]

111. Jurga, A.M.; Piotrowska, A.; Makuch, W.; Przewlocka, B.; Mika, J. Blockade of P2X4 Receptors Inhibits Neuropathic Pain-Related Behavior by Preventing MMP-9 Activation and, Consequently, Pronociceptive Interleukin Release in a Rat Model. Front. Pharm. 2017, 8, 48. [CrossRef] [PubMed]

112. Mika, J.; Zychowska, M.; Popiolek-Barczyk, K.; Rojewska, E.; Przewlocka, B. Importance of glial activation in neuropathic pain. Eur. J. Pharm. 2013, 716, 106-119. [CrossRef] [PubMed]

113. Gwak, Y.S.; Kang, J.; Unabia, G.C.; Hulsebosch, C.E. Spatial and temporal activation of spinal glial cells: Role of gliopathy in central neuropathic pain following spinal cord injury in rats. Exp. Neurol. 2012, 234, 362-372. [CrossRef]

114. Segal, J.P.; Tresidder, K.A.; Bhatt, C.; Gilron, I.; Ghasemlou, N. Circadian control of pain and neuroinflammation. J. Neurosci. Res. 2018, 96, 1002-1020. [CrossRef]

115. Moalem, G.; Tracey, D.J. Immune and inflammatory mechanisms in neuropathic pain. Brain Res. Rev. 2006, 51, 240-264. [CrossRef]

116. O'Brien, W.; Pham, L.; Symons, G.; Monif, M.; Shultz, S.; McDonald, S. The NLRP3 inflammasome in traumatic brain injury: Potential as a biomarker and therapeutic target. J. Neuroinflamm. 2020, 17, 104. [CrossRef]

117. Zhang, T.; Fang, Z.; Linghu, K.; Liu, J.; Gan, L.; Lin, L. Small molecule-driven SIRT3-autophagy-mediated NLRP3 inflammasome inhibition ameliorates inflammatory crosstalk between macrophages and adipocytes. Br. J. Pharmacol. 2020, 177, 4645-4665. [CrossRef]

118. Sun, X.; Cao, L.; Ge, J.; Ge, J.; Yang, X.; Du, B.; Song, J. The NLRP3-related inflammasome modulates pain behavior in a rat model of trigeminal neuropathic pain. Life Sci. 2021, 277, 119489. [CrossRef] [PubMed]

119. Arruri, V.; Gundu, C.; Kalvala, A.; Sherkhane, B.; Khatri, D.; Singh, S. Carvacrol abates NLRP3 inflammasome activation by augmenting Keap1/Nrf-2/p62 directed autophagy and mitochondrial quality control in neuropathic pain. Nutr. Neurosci. 2021, 1-16. [CrossRef] [PubMed]

120. Krajewski, J. P2X3-Containing Receptors as Targets for the Treatment of Chronic Pain. Neurother. J. Am. Soc. Exp. NeuroTher. 2020, 17, 826-838. [CrossRef]

121. Drill, M.; Jones, N.C.; Hunn, M.; O'Brien, T.J.; Monif, M. Antagonism of the ATP-gated P2X7 receptor: A potential therapeutic strategy for cancer. Purinergic Signal. 2021, 17, 215-227. [CrossRef] [PubMed]

122. Bernier, L.P.; Ase, A.R.; Seguela, P. P2X receptor channels in chronic pain pathways. Br. J. Pharm. 2018, 175, 2219-2230. [CrossRef]

123. Sperlágh, B.; Illes, P. P2X7 receptor: An emerging target in central nervous system diseases. Trends Pharmacol. Sci. 2014, 35, 537-547. [CrossRef]

124. Patapoutian, A.; Tate, S.; Woolf, C.J. Transient receptor potential channels: Targeting pain at the source. Nat. Rev. Drug Discov. 2009, 8, 55-68. [CrossRef]

125. Cortright, D.N.; Krause, J.E.; Broom, D.C. TRP channels and pain. Biochim. Biophys. Acta 2007, 1772, 978-988. [CrossRef]

126. Jordt, S.; Bautista, D.; Chuang, H.; McKemy, D.; Zygmunt, P.; Högestätt, E.; Meng, I.; Julius, D. Mustard oils and cannabinoids excite sensory nerve fibres through the TRP channel ANKTM1. Nature 2004, 427, 260-265. [CrossRef] [PubMed]

127. Zhao, M.; Isami, K.; Nakamura, S.; Shirakawa, H.; Nakagawa, T.; Kaneko, S. Acute cold hypersensitivity characteristically induced by oxaliplatin is caused by the enhanced responsiveness of TRPA1 in mice. Mol. Pain 2012, 8, 55. [CrossRef] [PubMed]

128. Shim, H.; Bae, C.; Wang, J.; Lee, K.; Hankerd, K.; Kim, H.; Chung, J.; La, J. Peripheral and central oxidative stress in chemotherapyinduced neuropathic pain. Mol. Pain 2019, 15, 1744806919840098. [CrossRef] [PubMed]

129. Boiko, N.; Medrano, G.; Montano, E.; Jiang, N.; Williams, C.R.; Madungwe, N.B.; Bopassa, J.C.; Kim, C.C.; Parrish, J.Z.; Hargreaves, K.M.; et al. TrpA1 activation in peripheral sensory neurons underlies the ionic basis of pain hypersensitivity in response to vinca alkaloids. PLoS ONE 2017, 12, e0186888. [CrossRef]

130. Yosten, G.; Harada, C.; Haddock, C.; Giancotti, L.; Kolar, G.; Patel, R.; Guo, C.; Chen, Z.; Zhang, J.; Doyle, T.; et al. GPR160 de-orphanization reveals critical roles in neuropathic pain in rodents. J. Clin. Investig. 2020, 130, 2587-2592. [CrossRef]

131. Sayo, A.; Konishi, H.; Kobayashi, M.; Kano, K.; Kobayashi, H.; Hibi, H.; Aoki, J.; Kiyama, H. GPR34 in spinal microglia exacerbates neuropathic pain in mice. J. Neuroinflamm. 2019, 16, 82. [CrossRef] 
132. Karki, P.; Kurihara, T.; Nakamachi, T.; Watanabe, J.; Asada, T.; Oyoshi, T.; Shioda, S.; Yoshimura, M.; Arita, K.; Miyata, A. Attenuation of inflammatory and neuropathic pain behaviors in mice through activation of free fatty acid receptor GPR40. Mol. Pain 2015, 11, 6. [CrossRef]

133. Mao, X.; Wu, H.; Tang, X.; Ali, U.; Liu, H.; Wang, Y. Activation of GPR40 produces mechanical antiallodynia via the spinal glial interleukin-10/ $\beta$-endorphin pathway. J. Neuroinflamm. 2019, 16, 84. [CrossRef]

134. Nourbakhsh, F.; Atabaki, R.; Roohbakhsh, A. The role of orphan G protein-coupled receptors in the modulation of pain: A review. Life Sci. 2018, 212, 59-69. [CrossRef]

135. Gong, N.; Xiao, Q.; Zhu, B.; Zhang, C.Y.; Wang, Y.C.; Fan, H.; Ma, A.N.; Wang, Y.X. Activation of spinal glucagon-like peptide-1 receptors specifically suppresses pain hypersensitivity. J. Neurosci. 2014, 34, 5322-5334. [CrossRef]

136. Liu, J.; Yin, F.; Zheng, X.; Jing, J.; Hu, Y. Geniposide, a novel agonist for GLP-1 receptor, prevents PC12 cells from oxidative damage via MAP kinase pathway. Neurochem. Int. 2007, 51, 361-369. [CrossRef]

137. Zhu, B.; Gong, N.; Fan, H.; Peng, C.; Ding, X.; Jiang, Y.; Wang, Y. Lamiophlomis rotata, an orally available Tibetan herbal painkiller, specifically reduces pain hypersensitivity states through the activation of spinal glucagon-like peptide-1 receptors. Anesthesiology 2014, 121, 835-851. [CrossRef] [PubMed]

138. Roger, B.; Papin, J.; Vacher, P.; Raoux, M.; Mulot, A.; Dubois, M.; Kerr-Conte, J.; Voy, B.; Pattou, F.; Charpentier, G.; et al. Adenylyl cyclase 8 is central to glucagon-like peptide 1 signalling and effects of chronically elevated glucose in rat and human pancreatic beta cells. Diabetologia 2011, 54, 390-402. [CrossRef] [PubMed]

139. Ramos, L.; Zippin, J.; Kamenetsky, M.; Buck, J.; Levin, L. Glucose and GLP-1 stimulate cAMP production via distinct adenylyl cyclases in INS-1E insulinoma cells. J. Gen. Physiol. 2008, 132, 329-338. [CrossRef] [PubMed]

140. Baggio, L.L.; Drucker, D.J. Biology of incretins: GLP-1 and GIP. Gastroenterology 2007, 132, 2131-2157. [CrossRef]

141. Reed, J.; Bain, S.; Kanamarlapudi, V. Recent advances in understanding the role of glucagon-like peptide 1. F1000Research 2020, 9. [CrossRef]

142. Wu, H.; Tang, X.; Mao, X.; Wang, Y. Autocrine Interleukin-10 Mediates Glucagon-Like Peptide-1 Receptor-Induced Spinal Microglial $\beta$-Endorphin Expression. J. Neurosci. Off. J. Soc. Neurosci. 2017, 37, 11701-11714. [CrossRef]

143. Alavi, S.; Ebrahimi Shahmabadi, H. GLP-1 peptide analogs for targeting pancreatic beta cells. Drug Discov. Today 2021, 26, 1936-1943. [CrossRef]

144. Geng, X.; Wang, F.; Tian, D.; Huang, L.; Streator, E.; Zhu, J.; Kurihara, H.; He, R.; Yao, X.; Zhang, Y.; et al. Cardiac glycosides inhibit cancer through Na/K-ATPase-dependent cell death induction. Biochem. Pharmacol. 2020, 182, 114226. [CrossRef]

145. Patel, S. Plant-derived cardiac glycosides: Role in heart ailments and cancer management. Biomed. Pharmacother. $=$ Biomed Pharmacother. 2016, 84, 1036-1041. [CrossRef]

146. Xue, X.; Deng, Y.; Wang, J.; Zhou, M.; Liao, L.; Wang, C.; Peng, C.; Li, Y. Hydroxysafflor yellow A, a natural compound from Carthamus tinctorius L. with good effect of alleviating atherosclerosis. Phytomed. Int. J. Phytother. Phytopharm. 2021, 91, 153694. [CrossRef]

147. Dey, S.; Jayaraman, N. Glycosidic bond hydrolysis in septanosides: A comparison of mono-, di-, and 2-chloro-2-deoxyseptanosides. Carbohydr. Res. 2014, 399, 49-56. [CrossRef]

148. He, W.J. Study on the Interaction of Milk Protein with Cyanidin-3-O-Glucoside and Its Effect on Pigment Stability; Jianggnan University: Wuxi, China, 2018.

149. Yu, H.; Xu, J.; Su, J.; Lu, W.; Lin, G. Synthesis of novel salidroside esters by lipase-mediated acylation with various functional acyl groups. J. Biosci. Bioeng. 2008, 106, 65-68. [CrossRef]

150. Verkhratsky, A.; Fernyhough, P. Mitochondrial malfunction and $\mathrm{Ca}^{2+}$ dyshomeostasis drive neuronal pathology in diabetes. Cell Calcium 2008, 44, 112-122. [CrossRef]

151. Simon, F.; Varela, D.; Cabello-Verrugio, C. Oxidative stress-modulated TRPM ion channels in cell dysfunction and pathological conditions in humans. Cell. Signal. 2013, 25, 1614-1624. [CrossRef]

152. Bubolz, A.; Mendoza, S.; Zheng, X.; Zinkevich, N.; Li, R.; Gutterman, D.; Zhang, D. Activation of endothelial TRPV4 channels mediates flow-induced dilation in human coronary arterioles: Role of $\mathrm{Ca}^{2+}$ entry and mitochondrial ROS signaling. Am. J. Physiol. Heart Circ. Physiol. 2012, 302, H634-H642. [CrossRef] [PubMed]

153. Nazıroğlu, M.; Ciğg, B.; Ozgül, C. Neuroprotection induced by N-acetylcysteine against cytosolic glutathione depletion-induced $\mathrm{Ca}^{2+}$ influx in dorsal root ganglion neurons of mice: Role of TRPV1 channels. Neuroscience 2013, 242, 151-160. [CrossRef]

154. Trevisan, G.; Benemei, S.; Materazzi, S.; De Logu, F.; De Siena, G.; Fusi, C.; Fortes Rossato, M.; Coppi, E.; Marone, I.M.; Ferreira, J.; et al. TRPA1 mediates trigeminal neuropathic pain in mice downstream of monocytes/macrophages and oxidative stress. Brain 2016, 139, 1361-1377. [CrossRef] [PubMed]

155. Nicke, A.; Bäumert, H.; Rettinger, J.; Eichele, A.; Lambrecht, G.; Mutschler, E.; Schmalzing, G. P2X1 and P2X3 receptors form stable trimers: A novel structural motif of ligand-gated ion channels. EMBO J. 1998, 17, 3016-3028. [CrossRef]

156. North, R. P2X receptors. Philos. Trans. R. Soc. Lond. Ser. B Biol. Sci. 2016, 371, 20150427. [CrossRef] [PubMed]

157. Suurvali, J.; Boudinot, P.; Kanellopoulos, J.; Ruutel Boudinot, S. P2X4: A fast and sensitive purinergic receptor. Biomed. J. 2017, 40, 245-256. [CrossRef] [PubMed] 